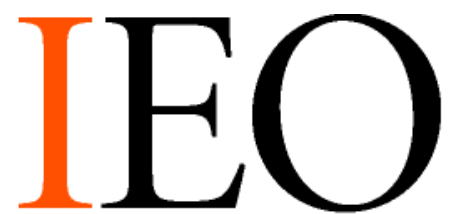

Independent Evaluation Office of the International Monetary Fund

$\mathrm{BP} / 18-02 / 02$

\title{
Assessing the FSAP: Quality, Relevance, and Value Added
}

Gerard Caprio, Jr. 


\section{IEO Background Paper}

Independent Evaluation Office

of the International Monetary Fund

Assessing the FSAP: Quality, Relevance, and Value Added

Prepared by Gerard Caprio, Jr.*

December 14, 2018

The views expressed in this Background Paper are those of the author and do not necessarily represent those of the IEO, the IMF, or IMF policy. Background Papers report analyses related to the work of the IEO and are published to elicit comments and to further debate. The author benefitted from discussions with and/or comments from Peter Montiel, the authors of the country and thematic background papers for this project, as from IMF staff and external experts. Nikolina Krisic and Joshua Wojnilower provided excellent and tireless research assistance.

* Professor of Economics, Williams College. 
Abbreviations iv

Executive Summary v

I. Introduction 1

II. Evolution of the FSAP Post-Crisis 2

III. FSAP Structure and Focus 4

A. Recommendations as a Guide to FSAP Focus 4

B. Increased Focus on Stress Tests and Risk Assessment 5

IV. Resource Costs 7

V. Relevance and Usefulness of the FSAP 11

A. Audience, Messaging, and Role 11

B. Coverage of Issues and Follow-up 15

C. Quality, Sophistication, and Breadth of Analysis 16

D. Use of Market Indicators 18

E. Topic Selection and New Issues 19

VI. Conclusions and Recommendations 21

Figures

1. Number of FSAPs 7

2. FSAP Personnel Cost, FY2010-17, FTEs 8

3a. Average Personnel Cost of FSAPs, FY2013-17 9

3b. Total Direct Personnel Cost of FSAPs, FY2010-17 9

4. FSAP Overall Labor Cost, S29 (+Euro Area), FY2008-17 10

5. FSAP Overall Labor Cost, Non-S29 Countries, FY2008-17 10

Appendix Tables

1. Jurisdictions with Systemically Important Financial Sectors 25

2. Spain: Key Financial Stability Recommendations (Near term) 26

3. China: Main Recommendations 27

4. Risk Assessment and Stress Testing: Spain, 2012 and 2017 29

5. Risk Analysis and Stress Testing: Germany, 2011 and 2016 31

References 34 


\section{AbBreviations}

ACES

AML/CFT

BCBS

$B C P$

CRA

DAR

DSGE

FSAP

FSB

FSSA

FSSR

FSIS

FTE

G20

GFC

GFSR

LIC

MCM

NRSRO

RAM

ROSC

SIP

SWIFT

TCFD

TRACES

WEO

WP
Activity Costing and Estimation System

Anti-Money Laundering/Combating the Financing of Terrorism

Basel Committee on Bank Supervision

Basel Core Principles for Bank Supervision

Credit Rating Agency

Detailed Assessment Report

Dynamic Stochastic General Equilibrium (model)

Financial Sector Assessment Program

Financial Stability Board

Financial System Stability Assessment

Financial Sector Stability Review

Financial Soundness Indicators

full-time [staff] equivalent

A grouping composed of major advanced economies and systemically important developing and emerging market countries

Global Financial Crisis

Global Financial Stability Report

low-income country

Monetary and Capital Markets Department

Nationally Recognized Statistical Rating Organization

Risk Assessment Matrix

Report on Standards and Codes

Selected Issues Paper

Society for Worldwide Interbank Financial Telecommunication

Task Force on Climate-Related Financial Disclosures

Time Reporting for ACES

World Economic Outlook

Working Paper 


\section{EXECUTIVE SUMMARY}

This paper examines the technical quality, relevance and usefulness of the Financial Sector Assessment Program (FSAP). The FSAP has become an increasingly sophisticated tool for evaluating the stability of financial systems and, for low- and middle-income countries (with the World Bank), a tool to assess their financial development needs. It is regarded by country authorities as a high quality and rigorous exercise, although the quality does vary. Given that the regulatory pendulum fluctuates between more and less rigorous enforcement, the FSAP can serve to keep national authorities "on their toes," to disseminate cutting-edge techniques for assessing and modelling risk, and to examine cross-border threats to financial stability.

In response to the global financial crisis and in part as a result of the IMF's technical assistance and training efforts, country authorities have made great strides in their own ability to assess financial stability. Authorities are dedicating much more time and effort to understanding the risks facing their financial systems and have access to more data, including information that cannot be legally shared. In addition, the FSAP assessment of threats to financial stability can become outdated within 18 months to 2 years of the exercise, or even more quickly, given that financial risks can evolve rapidly, and financial institutions can change their risk profile quickly.

Although increasingly sophisticated, the FSAP's relevance, value added, and usefulness can be improved by greater focus, prioritization and integration with Article IV consultations. A more flexible classification of countries with systemically important financial sectors might allow a broader group to be subject to more frequent FSAPs, with frequency determined more strategically and only the five most systemically important jurisdictions still subject to a mandatory, but perhaps leaner, FSAP every five years. Offsite analysis could be better used to decide which countries need a closer look as part of the IMF's surveillance, thus making better use of national authorities' time. The recent trend in which IMF staff teams have increased the amount of preparatory work preceding FSAP missions to focus on key issues and vulnerabilities should be reinforced. The IMF also might better tailor its stress-testing activities to the technical capacities of countries to conduct these tests on their own.

The IMF has undertaken several initiatives to better integrate financial and macrofinancial analysis into Article IV consultations, but this is still work in progress. More could be done to use these consultations to ensure effective higher frequency monitoring of financial stability risks, more consistent with the rapid evolution of financial sector risk. This would be anchored in periodic FSAP reports that would identify key risks as well as investigate structural issues in the sector. The IMF should continue strengthening the ability of Article IV teams to assess financial stability risks, building, if available, on the analysis of recent FSAPs. In support of these objectives, the IMF needs to continue increasing its expertise and skills in the financial sector, developing both world class experts and deeper macrofinancial skills among the broader economist group, including area department country teams. 



\section{INTRODUCTION}

1. In the wake of the global financial crisis (GFC), the IMF substantially increased the focus of its work in the Financial Sector Assessment Program (FSAP) on financial stability. Initially, in the 1990s, the FSAP was a voluntary program, built around comprehensive assessments of a variety of standards, with Reports on Standards and Codes (ROSCs) being a key part of the exercise. This broad remit was consistent with the joint nature of the Bank-Fund program, which was set up to examine both the development and stability issues of financial systems. The 2009 FSAP Review (IMF and World Bank, 2009) called for enhancements to the quality, candor, and comparability of the assessments; a move to greater flexibility of the program; and greater focus by the Fund, which has sole responsibility for advanced economy FSAPs, on financial sector stability. ${ }^{1}$ In 2010 , the IMF made it mandatory for 25 jurisdictions identified as having systemically important financial sectors to undergo assessments under the FSAP; these assessments are discussed by the Executive Board ("the Board") in the context of the corresponding Article IV consultation. ${ }^{2}$ The 2014 FSAP Review pushed further in this direction, increasing the analytical foundations of FSAP assessments, giving greater emphasis to stress testing of banks and other financial institutions, and a greater focus on macro-prudential issues (IMF, 2014b).

2. This paper examines the technical quality, relevance, and usefulness of the FSAP, emphasizing the period since the 2014 Review and applying the lens of the program's likely contribution to reducing the frequency and magnitude of financial crises. The paper draws on previous IMF FSAP reviews and IEO evaluations of the FSAP; selected Financial Sector Stability Assessments (FSSAs) and other FSAP outputs; Article IV staff reports, the 2014 Triennial Surveillance Review (TSR) (IMF, 2014c); various Global Financial Stability Reports (GFSRs); and country and other background studies for this and earlier IEO evaluations. It also draws on discussions with academics and other outside experts, as well as with current and former IMF staff and officials from IMF member countries.

3. Section II reviews the evolution of the FSAP as a surveillance tool since the GFC. Section III looks at the structure and coverage of recent FSAPs. Section IV examines FSAP resource costs and allocation. Section $\mathrm{V}$ discusses the relevance and usefulness of the FSAP,

\footnotetext{
1 The stability assessments were to concentrate on an evaluation of the main risks to macrofinancial stability, an assessment of the country's financial policy framework, and assessment of the authorities' capacity to manage and resolve a financial crisis (IMF and World Bank, 2009).

${ }^{2}$ The IMF prepares a FSSA as part of the FSAP, focusing on financial stability issues and summarizing the FSAP for the IMF Executive Board. In this report we use FSAP to refer to the whole program as well as to the FSSA. The IMF also conducted eight FSAP "Stability Modules" during 2000-17, and the World Bank four "Development Modules" in the same period. These modules should be thought of as streamlined FSAPs with a focus consistent with their titles. Additionally, there used to be streamlined FSAP Updates, but these were discontinued after the 2009 Review. The FSAP has a development component, led by the World Bank. This aspect of the program is not examined in this report.
} 
drawing on the country studies that are part of this evaluation. Section VI concludes and makes recommendations to optimize the relevance and value added of the FSAP program.

\section{EVOLUTION OF THE FSAP POST-CRISIS}

4. Although the FSAP was created by the IMF and the World Bank in the late 1990s in the wake of the East Asian crisis, during most of its first decade it was not focused on systemic risk, either in its country coverage or regarding the issues highlighted. To be sure, there were some excellent assessments led by experts with substantial experience in the financial sector that contained a good analysis of the stability and development challenges in the sector. However, the program was a voluntary, technical assistance program for all countries.

5. Not only was the U.S. not assessed until after the crisis, ${ }^{3}$ but most of the pre-crisis assessments in other countries missed the extent of vulnerabilities that were exposed by the crisis. For example, although some risks were noted, the IMF concluded that the banking systems in both Ireland (IMF, 2006a) and Spain (IMF, 2006b) were sufficiently well capitalized to withstand a slowdown in growth; Ireland received top marks on the Basel Core Principles Assessment, notwithstanding the alarmingly rapid rates of credit growth and even though it was not enforcing its own regulations. ${ }^{4}$ Two years later, and only weeks before the country's top three banks went into receivership, the Iceland FSAP sounded more alarms, but the recommendations in the FSSA report were too measured for a banking system whose assets had risen from 100 percent of GDP in 2004 to over 900 percent in 2007 (IMF, 2008). As Goldstein (2017) notes, Belgium, Portugal, Spain, and the U.K. all received either a "clean bill of health" or a mixed assessment with reassuring stress test results in their 2006 FSAPs, and only in the 2006 FSAP for Denmark was there a clear warning.

6. These oversights and the voluntary nature of the program reflected in part the view that systemic financial crises were only an issue for low- and middle-income countriesnotwithstanding the experience of Japan and Sweden. Financial regulation was thought to be sufficiently robust in high-income countries, which provided the model for the various best practice standards and codes, a focal point of early FSAPs. Moreover, in the latter economies, the prevalent approach to financial regulation was the "light touch" model, reflecting the view of some regulators that a well-governed financial intermediary could best oversee its own risk. Unfortunately, there was little analysis of the governance failures in financial intermediaries, some of which had compensation policies that literally were looting the firms, in the sense of Akerlof

\footnotetext{
${ }^{3}$ The U.S. authorities did not volunteer for the program, the thinking apparently being that with all of the analysts following U.S. financial institutions, there would be little value added.

${ }^{4}$ Anglo Irish Bank, which had been growing at a dangerous pace for a decade, was violating its own lending criteria (see Barth, Caprio, and Levine, 2012). It is remarkable that the (former) Irish Financial Regulatory Authority sent Anglo-Irish management a letter outlining its concerns, did not receive a reply for 2.5 years, and took no other action-yet received high marks from the Fund.
} 
and Romer (1993). ${ }^{5}$ Basically, many observers, including the IMF, assumed that financial firms in rich countries were well-governed and had the incentive to safeguard their own viability. Intellectually this view was consistent with that in academia that financial markets could "slice and dice" risk, allocating it to those who could best bear it; if the boards of firms were not doing their job, the share price would suffer, and the board members would be replaced. Voices contradicting this majority view (Borio and White, 2004; Rajan, 2005) were largely ignored.

7. Importantly, the light touch approach was based on a "one risk, one bank at a time" view, also sometimes referred to as a microprudential or bank supervisor view, which assumed that risk could be separately and independently assessed, and that if each bank were managing its risk properly, the system as a whole would be stable. Although many came to recognize the problems with this view only after the GFC, Persaud (2000) and Danielsson and others (2001) had written eloquently on the problem with this reasoning long before the crisis (see Caprio, 2014, for a review). That Persaud paper's title alone ("Sending the herd off the cliff edge: the disturbing interaction between herding and market-sensitive risk management practices"), in addition to the prestigious prize it won (the Jacques de Larosiere Prize, named after a highly regarded former IMF Managing Director) did not lead to more attention to the dangers of a solely microprudential approach is consistent with the deep entrenchment of the light-touch, efficient markets view. Prior to the crisis, in many supervisory agencies and in the Basel Committee on Bank Supervision (BCBS), the microprudential view dominated. In the IMF, there was a clear separation between the FSAP and Article IV surveillance; neither the FSAP nor macrofinancial research more generally was featured or even mentioned much in Article IV documents (Caprio, 2011).

8. Following the GFC, reflecting widespread recognition of the need for attention to be paid to the overall financial system and the importance of a macroprudential view of the financial sector, the Fund's approach to financial surveillance was substantially overhauled. In particular, the FSAP was refocused in 2009 on three main pillars (i) identifying key financial vulnerabilities and assessing the resiliency of the financial sector; (ii) assessing the overall financial sector policy framework and management; and (iii) examining financial sector safety nets and resolution mechanisms. Standards and codes assessment became less central to the exercise. Rather than being required, the IMF now determines, after discussion with country authorities and a desk review of changes since the last assessment, on whether to undertake standards and codes assessments in each FSAP.

9. Going further, in 2010 assessments under the FSAP were made mandatory for a list of 25 jurisdictions judged to have systemically important financial sectors-formally recognizing FSAPs as a surveillance tool. The criteria for the systemically important designation emphasized the size

\footnotetext{
${ }^{5}$ The authors develop a model, applied to the U.S. Savings and Loan crisis of the 1980 s-90s, in which bankers take high risks and then pay themselves out of the short-term profits, ignoring the likelihood of longer-term losses. When their bonuses are cashed out in advance of the realization of losses, they have in effect looted their bank. Bebchuk, Cohen, and Spamann (2010) argue that this incentive system was at work in the GFC.
} 
and interconnectedness of the financial systems (IMF, 2010). Subsequently, in 2013, citing advances in the modelling of interconnectedness, the Board decided to expand this list to 29 countries, referred to as the S29. The full list is shown in Appendix Table 1.

10. These changes occurred against the backdrop of a global effort led by the Financial Stability Board (FSB) to overhaul the international financial regulatory architecture. Essentially, the international community has agreed on the following pillars of financial stability: stress-testing, capital (via a relatively modest increase in required capital ratios), liquidity ratios, better bank resolution methods, and increased supervisory diligence, relative to the pre-crisis period, to keep financial systems safe, as well as on process-oriented improvements to regulation and supervision. Since the crisis, the FSAP can be thought of as an additional element to these components, essentially to provide international monitoring to ensure that they are all functioning well together.

\section{FSAP STRUCTURE AND FOCUS}

11. FSAPs focus on the threats to financial stability and the resilience of the financial system to plausible but stressful events or shocks. Resilience is judged by the ability of the financial institutions to absorb these shocks, as well as the capacity of the broader institutional setting and processes (safety net, resolution methods) to cope. In recent years, FSSA reports typically have included: an analysis of the macroeconomic setting and risks to financial stability; consideration of possible spillover effects (across sectors and countries); an analysis of structural policies to enhance financial stability, such as the financial safety net; authorities' preparations for crisis management; and usually the most important findings from assessments of standards and codes that are conducted as part of the FSAP. Low- and middle-income country assessments include attention to the developmental needs of the system, including what can be done to strengthen financial sector infrastructure-accounting, auditing, and the legal framework-and financial inclusion, issues assigned to the World Bank.

\section{A. Recommendations as a Guide to FSAP Focus}

12. Perhaps the best way to understand the FSAP is to look at its key prioritized recommendations for financial stability, which are found in Table 1 in each FSSA. Those recommendations and a Risk Assessment Matrix (RAM) are useful focal points to understand the exercise. As an illustration, Appendix Table 2 of the October 2017 Spain FSSA (IMF, 2017a) shows the key priorities from that FSAP, grouped into categories; many of the recommendations are of varying immediateness, notwithstanding the reference to the "near term." ${ }^{6}$ For example, recommendations related to fostering the development of market-based financing (7), setting up

\footnotetext{
${ }^{6}$ Many FSAPs list short-term and medium-term priorities, though the usage of these terms is not uniform across all reports. Most FSSA Table 1s feature both short-term and medium-term recommendations. Earlier FSSAs often did not state which agency or part of government should take the lead, whereas more recently that specificity (in the last column of Table 1) has become more frequent.
} 
a systemic risk council (10), and expanding the macroprudential toolkit (11) are processes that can be initiated but would not come to fruition soon. Moreover, some recommendations have featured in numerous reports for other countries, e.g., the establishment of a systemic risk council, developing the resolution process or strengthening deposit insurance, though the details in the text certainly vary across countries. Appendix Table 3 shows the summary table of recommendations from the 2017 China FSSA (IMF, 2017c). A few similarities (e.g., a systemic risk council) and many differences stand out vis-à-vis that for Spain. There are many more categories and recommendations - 35 for China, more than double that for Spain-reflecting a larger financial system and a much larger team (48, including 15 from the World Bank), commensurate with the rapidly growing and changing Chinese financial system.

13. The mix of recommendations differs among countries. For example, reports on countries with poorly developed safety nets might dwell more on the steps needed in that area, while emerging market and developing country FSSAs often include recommendations on market development, especially where these measures could have stability implications. In a recent India FSSA (IMF, 2017d), the IMF team recommended a gradual reduction in the Statutory Liquidity Ratio to help deepen markets. Reflecting the challenges in its financial system, the 2017 China FSSA included more categories and recommendations related to the nonbank financial sector (shadow banks and insurance companies) and the supervision of financial market infrastructure. ${ }^{7}$

14. FSAPs might have many dozens of recommendations, but the process of sorting out which ones make the first table of the FSSA (and therefore more likely to be seen by the IMF Board and to be reviewed in subsequent Article IV consultations) serves as a discipline to the team. The downside of this sorting process, as discussed below, is that recommendations that do not make it into the FSSA only appear in technical annexes and are not subject to regular follow-up by the Fund until possibly in the next FSAP.

\section{B. Increased Focus on Stress Tests and Risk Assessment}

15. Since 2010, as part of the increased focus on financial risks and reflecting an important shift in regulatory philosophy in the wake of the GFC, FSAPs have placed much greater emphasis on stress testing. Stress-testing has moved from only looking at solvency to also focusing on liquidity analysis, reflecting the lesson that capital might appear adequate, but liquidity quickly can dry up in periods of stress. Recent FSAP stress tests also go beyond looking at the initial impact to consider more in depth the role of cross-sector and cross-border feedback effects. The

\footnotetext{
7 The FSAP for China also included Detailed Assessment Reports (DARs) on the observance of the Basel Core Principles (BCP), IOSCO Objectives and Principles for Securities Regulations, and the Insurance Core Principles; these DARs presented detailed assessments and assigned grades to the observance of core principles and standards. The China FSSA also included Technical Notes on the Systemic Oversight of Financial Market Infrastructures and on AML/CFT. Such Technical Notes are intended to provide more detailed supporting analysis but not a formal assessment of observance or compliance. The 2017 FSSA for Spain also included a technical note on the Supervision of Spanish banks focused on areas highlighted in the previous FSAP and that still needed improvements; this note did not attempt to reassess compliance with the BCP, which was part of the 2012 FSAP, most notably because banking supervision in Spain, as in all other Euro Area Member States, fundamentally changed with the entering into force of the Council Regulation (EU) No. 1024/2013 (the so-called SSM Regulation), whereby the ECB was assigned this task.
} 
Fund also has begun applying stress testing to the non-bank financial sector including for example the insurance sector and the asset management sector.

16. These stress tests combine information about individual institutions with macroeconomic information to simulate how financial intermediaries will cope with a variety of "extreme but plausible" shocks relative to the most recent baseline projections. Information on individual institutions comes from annual reports, regulatory filings, market sources, and typically also from confidential supervisory data (although in some jurisdictions it is not feasible or legal for this information to be provided to the IMF).

17. Discussion of risks and stress testing analysis is typically structured around a RAM. To illustrate, Appendix Table 4 summarizes the key points from the RAM for the two most recent FSSAs for Spain (IMF, 2012; 2017d) and Appendix Table 5 contains the corresponding table for the two most recent FSSAs for Germany (IMF, 2011; 2016a). In the case of Spain, the stress tests have become more sophisticated, moving away from mainly studying macro risks to financial stresses more closely related to the risks in the RAM. The later FSAPs also contain a more thorough examination of interconnectedness and spillover risks, using a variety of methods to do so and taking into account these risks using interbank market and cross-sector analysis (bank, insurance companies and mutual fund linkages).

18. Use of stress testing in the FSAP has benefited from analysis featured in the GFSR. Thus, the April 2014 GFSR (IMF, 2014a) emphasized the issue of shadow banking and the non-bank financial sector, and recent FSAPs have extended stress testing beyond the banking sector (depending on the financial system under investigation). Many GFSRs (IMF, 2016b and earlier) and other reports (notably papers from the Bank for International Settlements (BIS)) have warned of the dangers posed by a long period of low interest rates, and this theme has been featured in several FSAPs, notably Germany and the Netherlands. Indeed, several FSAPs have analyzed corporate sector vulnerability using detailed corporate balance sheet data (e.g., Italy 2013, Turkey 2017, Mexico 2017, and Brazil 2018), and the Netherlands FSAP looked at income panel data.

19. A valuable feature of recent FSAPs is an evaluation of how well the authorities are assessing risks facing the financial sector to identify gaps in the regulatory system. Many central banks and supervisory agencies have made significant progress in strengthening financial sector supervision and regulation, but gaps or areas for further improvement are still often identified in FSAPs. In some cases, the issues involve data or skills, for example to conduct sufficiently detailed stress tests of the financial system (e. g., China, India, Zambia), and the IMF has offered technical assistance to help in the upgrading process. In some cases, FSSAs urged authorities to increase the resources for supervising the financial system (e.g., China).

20. In many cases, concerns about possible gaps have been cited, for example in euro area countries in the transition to a new regulatory and supervisory architecture. As noted above in the discussion of Appendix Table 2 for Spain and Appendix Table 3 for China, the IMF has 
adopted the view that countries need to have a Systemic Risk Council for inter-agency coordination on systemic risk factors and on financial sector policy.

21. The Fund also has employed the FSAP to promote crisis preparedness and management. An important issue is whether authorities are set up and prepared to manage bank and other financial institutions' resolution, including by running fire drills in advance of crises. In this vein, the IMF has urged attention to financial system safety nets, in particular to ensure that support for institutions is well designed before a crisis. In this context, deposit insurance systems are carefully evaluated, although the Fund has not recommended depositor protection across the board, and has stated in some FSSAs (e.g., Zambia) that preconditions (including a stable macro and financial environment and an effective resolution system) for the introduction of a deposit insurance system have not yet been met (see IMF, 2017b).

\section{ResouRCE COSTS}

22. The FSAP deploys significant resources, which increasingly have been allocated to S29 jurisdictions. This shift is seen both in terms of the rising share of FSAPs in S29 jurisdictions and their rising average cost. In the 2002-09 period, only about one in five FSAPs were for this group. Since then, this ratio is just over a third and even higher in the most recent years (Figure 1). At the same time, there was a decline in FSAPs in non-29 jurisdictions, with only 12 in the last two years.

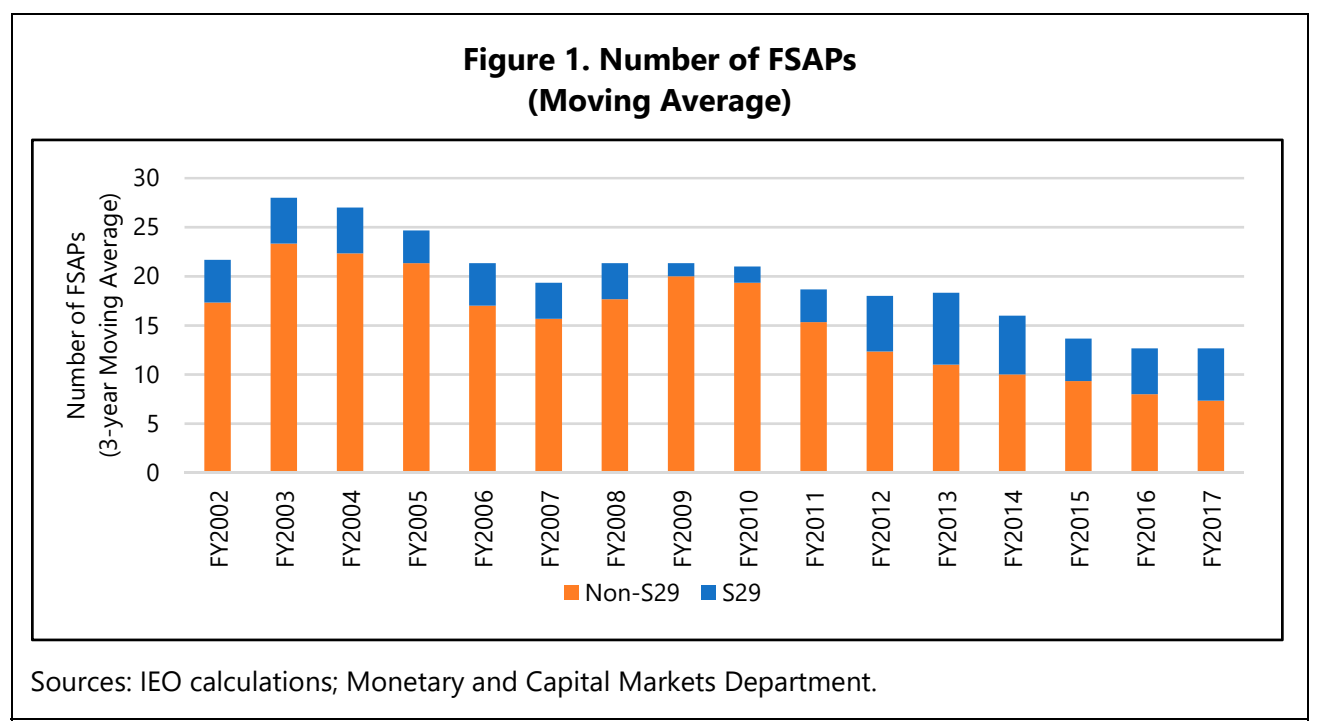

23. Several factors were behind these recent trends. First, IMF staff noted that they had made a deliberate decision to cap FSAPs at 12-14 per year due to resource constraints. Second, several of the S29 FSAPs took a sizeable chunk of resources, including China, Spain, India, and Japan in 2017, the U.K. and Germany in 2016, and the U.S. in 2015, which taken together may have crowded out some non-S29 countries. Third, the demand for FSAPs in non-S29 countries might have been influenced by political factors, e.g., since the "Arab Spring," FSAPs for countries 
covered by MCD have been fewer than in the past, as political change might have crowded out attention to financial sector issues among domestic policy makers. Finally, it is possible that country authorities from the non-S29 did not request FSAPs because they knew that given the limited resources, S29 countries would receive priority. ${ }^{8}$

24. The importance of the S29 is even more evident in terms of the cost of the program (excluding travel). As shown in Figure 2, FSAPs for these jurisdictions have accounted for just under 60 percent of the total cost of FSAPs (about 300 staff years or FTEs) since 2010 (Figure 2), when the Board decided to require an assessment every 5 years. Further, the 5 jurisdictions with the most systemically important financial sectors (U.S., Euro area, Japan, U.K and China, or S5) accounted for a third of the spending in the broader S29 group. With the focus more on larger and more complex financial systems, the average cost of an FSAP has mounted considerably (Figure 3a). These averages hide substantial variation. Figure $3 \mathrm{~b}$ shows the annual variation in total spending on S29 and non-S29 FSAPs.

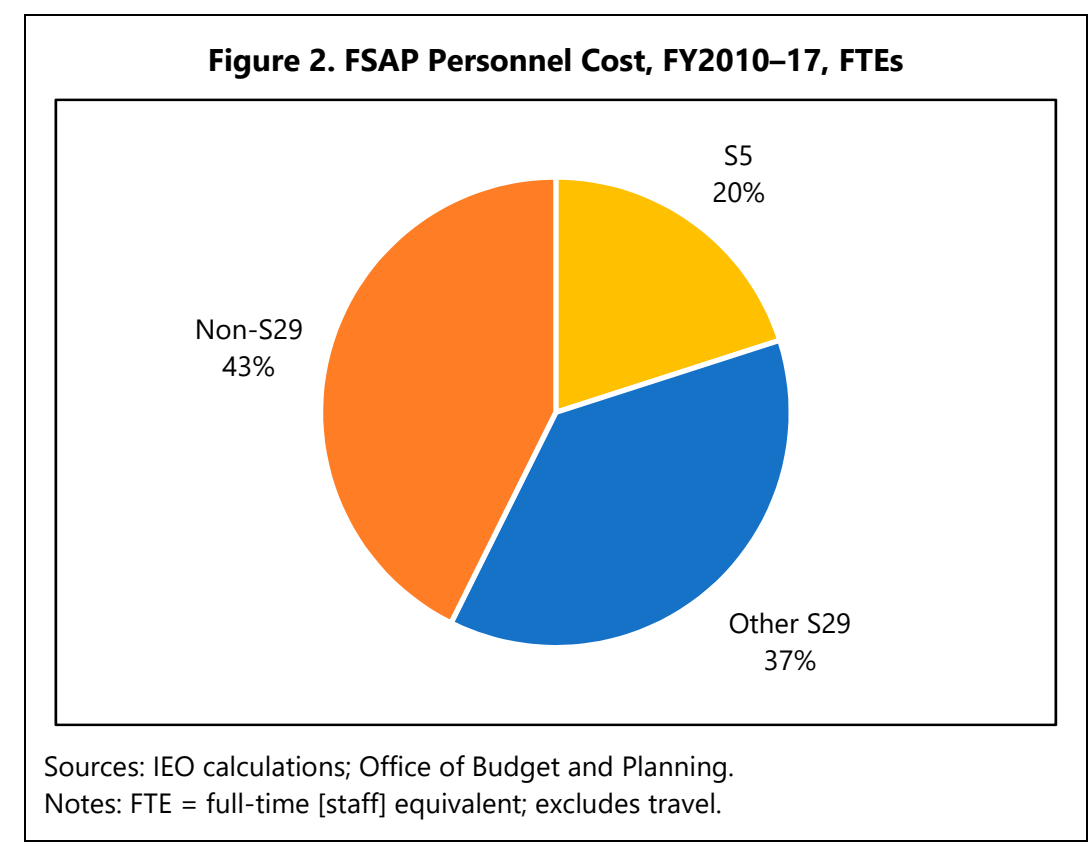

\footnotetext{
${ }^{8}$ IEO country case studies for Kenya, Ghana, and Nigeria (Ncube, 2018) and Malaysia, Singapore, and Thailand (Cheong, 2018) indicate some unmet demand for Fund advice and TA on financial issues.
} 


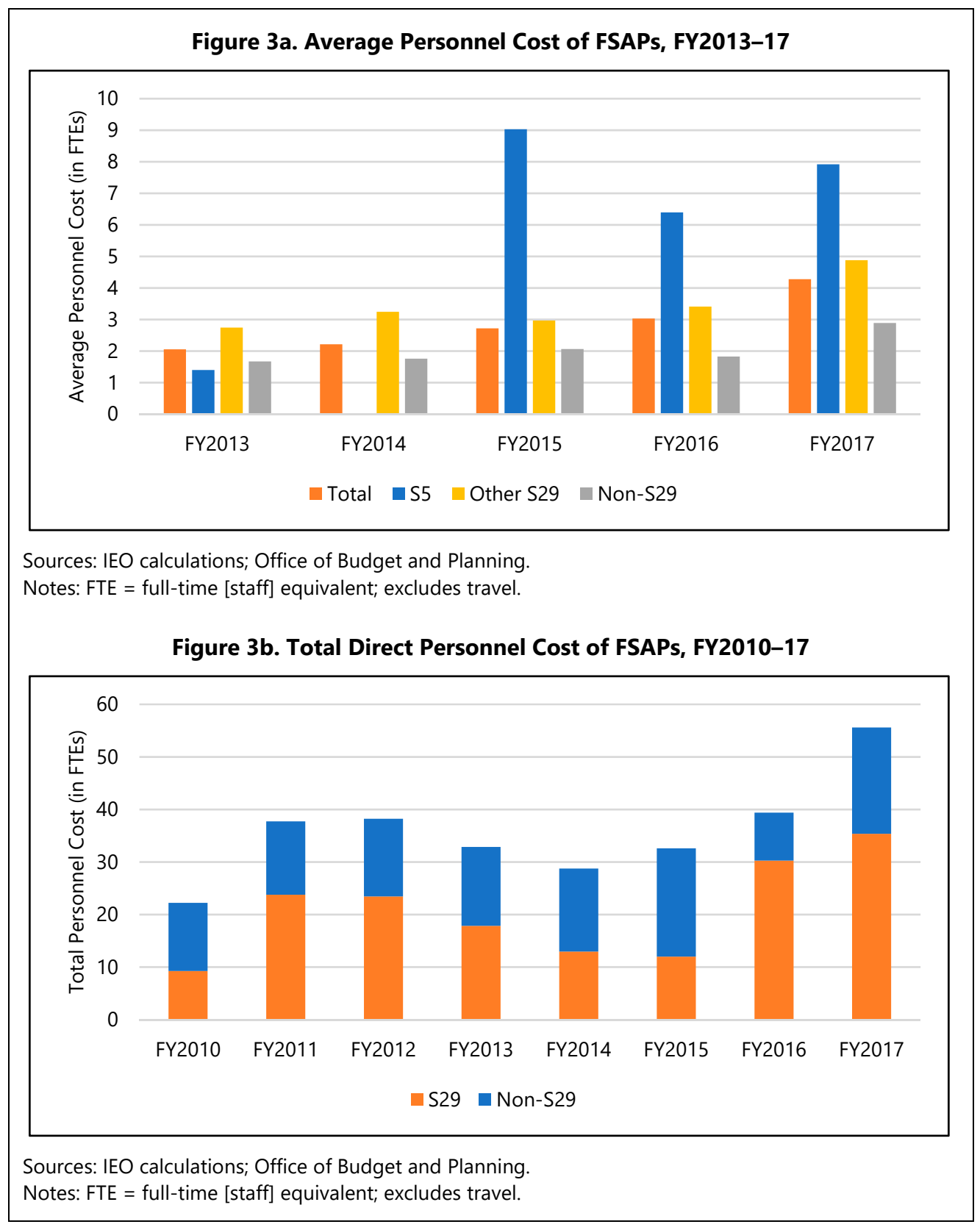

25. Figures 4 and 5 (also in FTEs) show the variation in cost across the S29 and non-S29 countries, with the most expensive FSAP (China 2017) many orders of magnitude more expensive than the least costly (Aruba, 2009, not visible in Figure 5). These data are only for the IMF side of the assessment; for countries in which a joint assessment was undertaken, World Bank costs are not included. In addition, no data is available on the cost to country authorities. In the absence of data, one might assume for $\mathrm{S} 29$ countries that the cost to the authorities (staff compensation) was roughly on the same order of magnitude as the cost to the Fund, meaning that the total labor costs of S29 FSAPs during the 2010-17 period would have been over $\$ 100$ million, with the IMF covering $\$ 53$ million. 


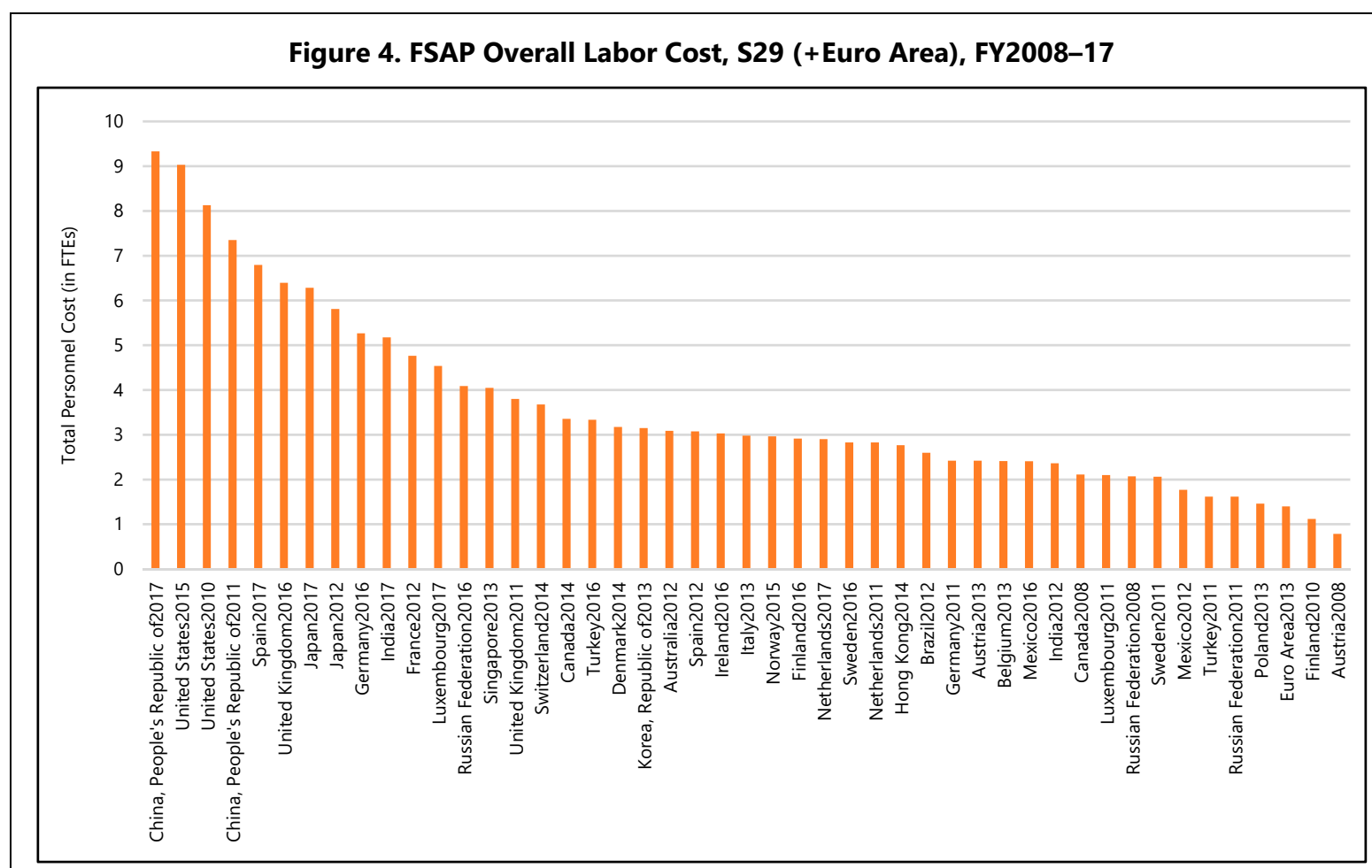

Sources: IEO calculations; Office of Budget and Planning. Notes: FTE = full-time [staff] equivalent; excludes travel.

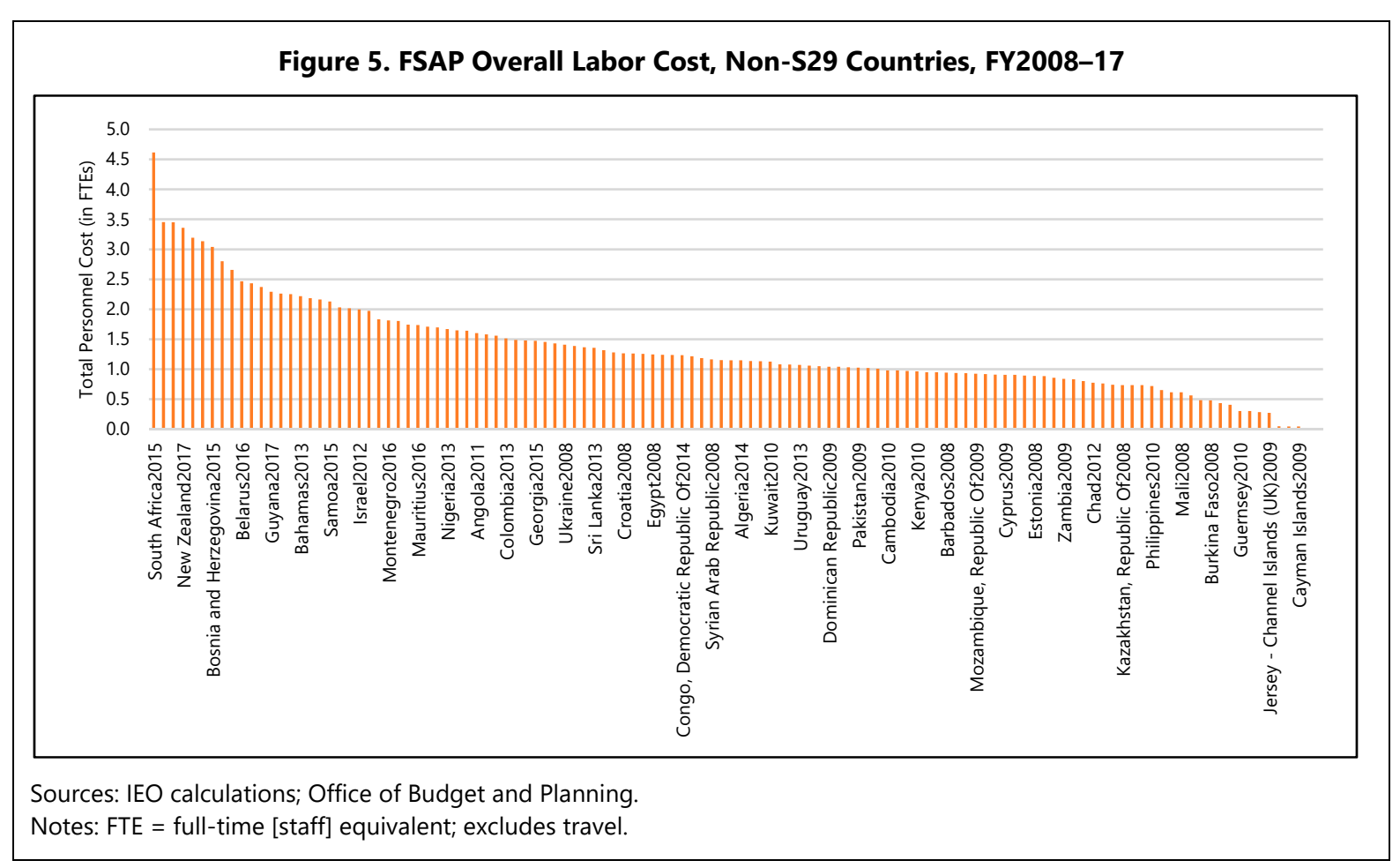


26. FSAPs for the $\mathbf{S} 29$ countries have grown costlier over time, even as the expertise of authorities in these countries has improved. It should be understood that the surveillance of large and complex financial systems is expensive, though the benefit of the increased costs is less clear. While much lower, the unit cost of FSAPs for non-S29 countries has also risen. The share of spending on non-S29 FSAPs has declined since 2010, but at the same time the Monetary and Capital Markets Department (MCM) increased annual personnel spending on technical assistance from $\$ 27$ in 2010 to $\$ 39$ million in $2017 . .^{9}$ These sums complement the cumulative total of $\$ 39$ million (in 2017 U.S. dollars) spent on non-S29 FSAPs during the FY 2010-17 period. Some stratification of resource allocation clearly is taking place beyond the S29 vs. non-S29 breakdown. In the period covered by Figures 3 and 4, about 10 FSAPs consumed more than 5 staff years each, another 20 FSAPs cost between 3 and 5 staff years each, and the remaining 139 FSAPs were under that level (about two-thirds of the latter at less than one staff year).

\section{Relevance AND Usefulness Of the FSAP}

27. This section looks first at the various audiences for the Program, as the relevance and usefulness of the FSAP likely depends on the vantage point of the observer. The discussion then turns to the coverage of issues and their follow-up, as well as the quality of the analysis and omitted issues.

\section{A. Audience, Messaging, and Role}

28. The most relevant audience for the FSAP varies by country. Possible target audiences are the authorities in the country being assessed, authorities in other countries, financial market participants in the country and around the world, academia; and the global community. ${ }^{10}$ In addition, the FSB peer review teams typically look closely at FSAP outputs. ${ }^{11}$

29. In some cases, the authorities in countries being examined see the FSAP's value mainly in terms of third parties. For example, Miles (2018) interprets U.K. authorities as valuing the FSAP as a check-up by an independent and reputable third party, particularly as the U.K. prepares for Brexit, in effect appreciating the process and the presumably positive assessment they receive rather than looking to the IMF team to identify risks or issues of which they were unaware.

\footnotetext{
${ }^{9}$ These figures include external financing and are reported in constant 2017 U.S. dollars. Focusing only on Fundfinanced spending on technical assistance, the increase was from about 15 million to 19.5 million annually in constant 2017 U.S. dollar terms.

${ }^{10}$ Although they are subsumed in this list, the groups that wrote the various standards and codes-the BCBS, the International Organization of Securities Commissions (IOSCO), etc.-constitute groups interested in specific parts of the FSAP and indeed pre-crisis seemed to be a core constituency.

11 Beginning in 2010, the FSB began a system of peer reviews of implementation of agreed standards among its members (22 countries plus the Euro Area and Hong Kong SAR). To a large extent, these reviews overlap with the standards and codes assessments of the FSAP, though country officials note that the FSB peer reviews tended to be "friendlier" than assessments done by FSAP teams.
} 
Murray (2018) portrays U.S. authorities as willing to undergo a rigorous examination as a demonstration effect for other countries, and essentially as a way to motivate countries to improve their financial systems, rather than in the expectation that they will learn anything that is new and significant.

30. Although this view could be seen as hubris similar to that characterizing the pre-GFC era (as Murray notes), it is also the case that the authorities in the U.S., the U.K, and most other high-income countries are devoting many times the level of resources to regular stress testing and surveillance of their own financial systems as the IMF can devote during the FSAP. Moreover, member country officials stressed that a 5-year interval was too long for identifying risk given the potentially rapid changes in financial markets. Some current and former IMF staff and a number of outside observers concurred that the FSAP teams are unlikely to discover issues that regulatory authorities in most advanced countries might have missed. For these countries, the value of an FSAP to the authorities may largely center round an opportunity to exchange views with a trusted advisor and to explore lessons from the latest stress tests in other countries, and/or evidence of cross-border risks that the IMF believes deserve added weight.

31. Consistent with this view, many observers in advanced countries suggested that the FSAP had a high value added in the immediate aftermath of the crisis but is now subject to diminishing returns. Resources, training and skill levels have increased in most countries. In many advanced economies and some emerging economies, the authorities are regularly running their own stress tests with ever more granular data, some of which is not legally available to the Fund or only available under restricted conditions. ${ }^{12}$

32. Fund staff continues to put a high value on the stress testing exercise. They argued that maintaining stress test expertise required the Fund to continue to "get its hands dirty," not just provide high-level commentary. They pointed out that stress-testing standards vary quite widely across jurisdictions (as confirmed in a 2017 BCBS review), and that the Fund can still play an important role in developing and disseminating new techniques beyond traditional bank solvency stress tests, including liquidity stress tests, stress tests of non-bank intermediaries, and system-wide stress tests. ${ }^{13}$

33. Another common complaint by authorities is that the FSAP exercise imposes a high burden on their agencies, with overlapping and not always well thought out requests that place

\footnotetext{
12 On the other hand, IMF staff indicated that even in jurisdictions with sophisticated micro-level stress tests, FSAPs have found major gaps in authorities' macrofinancial stress testing.

13 This evaluation found reports of some value added, e.g., a German official explained that the 2016 IMF stress tests were highly regarded by the Bundesbank and had improved their own models (Anderson, 2018).
} 
significant demands on their staff's time. ${ }^{14}$ While the Fund is typically viewed as the most authoritative international interlocutor, opportunities for national regulatory authorities to communicate with one another on systemic risk issues have grown more pervasive, including with other counterparts (notably through the FSB peer reviews and various standards and codes committees). On the other hand, these opportunities are more limited for low- and many middleincome countries (e.g., those not members of the FSB or the BCBS).

34. A strength of the FSAP program according to IMF staff and some country authorities is that it forces communication across different domestic regulatory agencies within a country. In many countries, financial regulatory authority can be fragmented, and cross-regulator communication and coordination is much less regular than many believe worthwhile. This view provides a rationale for the frequent FSSA recommendation for some umbrella group bringing regulatory agencies in a country together to evaluate and respond to risks. IMF recommendations to strengthen coordination could potentially add value in many countries, although establishing a forum for communication is notably easier than making it work effectively. ${ }^{15}$

35. An important contribution of FSAPs is that they serve to alert about the risk of regulatory backsliding. A periodic assessment of the system and highlighting of emerging regulatory or supervisory weaknesses remain relevant even where jurisdictions previously have passed scrutiny with flying colors. A common critique of financial markets is that their participants do not remember or were not around for a previous crisis, causing them to underestimate risk; the same can be said of regulators (and of FSAP participants), who might be less alert to risk in the later stages of a long period of economic prosperity and rising markets. While regulatory standards and vigilance might have been heightened after the crisis, there is no guarantee that this will remain so. One of the causes of the last crisis was a failure of microprudential regulation through regulatory capture, an ideology of skepticism of regulation and/or psychological bias (Johnson and Kwak, 2010; Barth, Caprio, and Levine, 2012). Whatever the cause, post-crisis reviews in Iceland, Ireland and the U.K. concluded that the regulatory agencies did not do their jobs. ${ }^{16}$ In many jurisdictions the pendulum is now swinging to ease up on the tightening of regulation and supervision that occurred after the GFC.

36. In practice, the value of an FSAP depends in part on timing. The 2012 FSAP for Spain came at an opportune moment when the Spanish authorities were grappling with resolution

\footnotetext{
${ }^{14}$ For example, the Chinese authorities indicated that the 2017 FSAP involved 550 meetings, up from 400 meetings for the 2011 FSAP (Dollar, 2018); the Japanese authorities referred to 250 meetings during the 2017 FSAP (Ariyoshi, 2018); and the U.K. authorities mentioned a much higher number of meetings (Miles, 2018).

15 The impact of IMF advice would depend on the incentives and culture among country officials. In interviews in a country with an interagency forum for exchanging information on supervisory concerns, a senior official mentioned that participants are reluctant to say anything that could reflect negatively on their or other agencies.

${ }^{16}$ See Barth, Caprio, and Levine (2012), Chapter 5 for sources, which in all cases were official government reviews.
} 
issues, and the team seemed to be able to encourage the authorities along that path. According to Veron (2016):

[s]enior Spanish and European officials who were interviewed for [this] evaluation concurred that thanks to this "serendipitous" [emphasis added] timing, FSAP missions had significant influence in helping the authorities to acknowledge the reality they were facing and prepare appropriate responses. The quality of the FSAP team and work was widely praised by Spanish and other European interviewees.

37. Had the Spanish assessment taken place a few years earlier or later, it likely would not have been nearly as useful. In the case of Italy, the 2011 FSAP raised issues about the balance sheets of banks, but the continued weak performance of the Italian economy exacerbated these difficulties, and in retrospect the FSAP warning appears muted (Anderson, 2018). On the other hand, the FSSA was clear about the governance failures in Banca Monte dei Paschi di Siena, and the lack of impact may have been because the audience was not ready for the messages (IMF, 2013).

38. In emerging and developing countries, the value added by the FSAP is easier to see in some cases than others. Dollar (2018) reports that the Chinese authorities highly regarded the 2011 and 2017 FSAPs, having implemented fully or largely 7 of the 11 priority recommendations from the former. According to Dollar while "the authorities did not always follow Fund advice, it was a critical input into their deliberations and decision-making." The 2012 FSAP for Nigeria was also influential in strengthening the regulatory environment in a number of aspects (Ncube, 2018). Many developing country regulators use the FSAP to compare their systems with others at comparable or somewhat more advanced levels of development. ${ }^{17}$

39. However, according to other IEO case studies, such as those for Brazil (Dhar, 2018), Mexico (de Bolle, 2018), and Southeast Asia (Cheong, 2018), country authorities were less appreciative of the FSAP, observing that their own expertise had increased greatly in recent years and that IMF teams had not always done sufficient preparation and were not always sufficiently cognizant of country circumstances to provide useful advice.

40. Given that the FSAP periodicity is at most once every five years and much longer for most non-S29 jurisdictions, country authorities observed that more follow-up in Article IV staff reports would be helpful. Some authorities welcomed the recent move to more in-depth coverage of financial and macrofinancial issues in the Article IV consultations in principle but noted that currently the value added of the Article IV financial sector analysis was substantially below that of FSAPs, reflecting that financial sector skills on Article IV mission teams were more limited.

\footnotetext{
17 Based on discussions with officials from low-income countries who have studied at the Center for Development Economics (Williams College) and also regulators who have participated in financial sector regulatory seminars at the World Bank from late-1990s through June 2017.
} 
41. Outside the official sector, the audience for FSAPs seems much more restricted. In the financial markets, it is difficult to find market participants who read the FSAP documents for many advanced S29 countries, even those who worked for firms taking relatively longer-term positions (and even former Bank and Fund staff who worked on FSAPs). On the other hand, for emerging markets, especially for those on which information is less available, the FSAPs seem to be more highly regarded as a source of information. Dollar (2018) noted that leading economists working on China regarded IMF reports as "...critical for data and useful for analysis." Market participants, particularly working for long-term investors confirmed that China's FSAP provided a wealth of information and analysis otherwise hard to obtain in a rapidly changing environment. Malaysian market participants also were reported to value the financial analysis in the FSAP (Cheong, 2018).

42. For the academic community, there is clearly potential for learning from FSAPs about the institutional detail in countries with limited other sources. However, it is remarkable that there are few articles in economics and finance journals that draw on the FSAP. Indeed, from 2006-18, the Journal of Financial Stability - a natural outlet for such papers-saw only a handful of submitted papers that either employed data or information from, or evaluated outputs of, the FSAP. Discussions with financial economists in academia also failed to reveal significant research in academic journals related to the FSAP.

\section{B. Coverage of Issues and Follow-up}

43. The relevance and usefulness of the FSAP to reducing the likelihood and severity of financial crises depends on the coverage of the reports and, where shortcomings are found, the follow up by the IMF and by country authorities. The coverage of issues in most FSAPs is fairly encyclopedic, a fortiori in larger countries, in line with the size of some of the teams, but the balance of attention can be questioned or there might be topics that will become important but are not getting attention.

44. Examples from the case studies of issues that received too little attention at least in the view of some observers included a lack of attention to: rapid expansion of credit by public sector banks in Brazil; consequences of possible unwinding of very low long-term interest rates in Japan; and the issues around inconsistent incentives among credit rating agencies in the U.S. (which was a significant factor in the crisis and yet was only mentioned in the 2015 FSAP in conjunction with one part of the IOSCO assessment).

45. These examples highlight two issues related to the relevance and usefulness of the FSAP in its stability function. First, stability was not always the primary concern when different standards and codes were devised; several capital markets experts involved with IOSCO argue that stability issues were not the focus of the drafters of those principles and that if a set of standards for the stability of capital markets were desired, it would be optimal to start over. Rather than providing an encyclopedic assessment of a wide variety of institutional issues, stability concerns should be the filtering device for inclusion in FSAPs. Second, it seems that a 
checklist orientation still exists in the FSAP: when there is a code to be assessed, it seems that following a set of procedures to assess that code-rather than analyzing how the financial sector is working, and specifically how incentives in the financial sector work to support or undermine financial stability-influence the team's work. Unfortunately, it was not possible to get a breakdown of time spent on various parts of the FSAP (e.g., standards assessment, stress testing, safety net or crisis preparedness evaluation, etc.)

46. Another way to enhance the relevance of FSAPs is by more consistently follow up on its recommendations. In addition to the recommendations that make it to Table 1 of the FSSA, each FSAP contains dozens of other recommendations in various supporting documents. While a subsequent FSAP will often look at what happened to the implementation of the main recommendations from a prior FSAP, such an investigation does not regularly happen relative to all of the report's recommendations. ${ }^{18}$ Moreover, although Article IV staff reports in the year of or following an FSAP include a copy of Table 1 of the FSSA, subsequent Article IV consultations often do not follow up even on the main FSAP recommendations (at least, not in their written documentation). In part this is due to the scarcity of financial sector expertise on those missions and that Article IV consultations are faced with multiple priorities (Takagi, 2018). The outcome seems to be that many FSAP recommendations are not pursued in IMF staff work for a substantial period of time, if at all.

\section{Quality, Sophistication, and Breadth of Analysis}

47. Just as opinions on the usefulness of a program like the FSAP vary depending on the audience, so too do views on the quality, relevance and sophistication of its analysis.

48. From the vantage point of this author-someone who was involved from the World Bank side in establishing the program and since 2006 has had low-income country students using information in or critiquing parts of individual FSAPs-it seems clear that the quality of the program as a diagnostic tool to detect sources of financial instability has improved. MCM and the Fund more broadly have brought in more staff with financial sector expertise and stepped up training on finance-related issues. However, as indicated in the case studies, country officials' perceptions of team quality vary, with teams for advanced economies typically receiving higher marks from authorities (except for still some complaints about inadequate preparation and insufficient familiarity with the previous FSAP). MCM senior staff pointed to the difficulty in attracting qualified financial sector staff and the broader shortage of financial skills in the Fund as a factor behind some variation in quality (Stedman, 2018).

49. One concern raised several times by authorities related to the basis for FSAP recommendations, and whether adequate account is taken of country circumstances. For example,

\footnotetext{
18 Strikingly, officials in some countries said that some team members did not seem to be familiar with the previous report (see Section V).
} 
the IMF apparently believes that regulatory agencies need to be devoting more attention to small banks, as this issue has arisen in a number of countries. As Miles (2018) notes, the superiority of a "bank examiner" approach has not been shown empirically, nor was there any discussion of tradeoffs of the benefits and costs of this approach when this recommendation was made by the U.K. FSAP. Unfortunately, this way of reaching "best practice" recommendations-based on the opinions of regulators and not grounded in empirical research-is one that pervades the regulatory community and continues, despite the severity of the crisis in some of the countries that originated this "best practice." The FSAP team certainly is well-placed to note practices in other countries, but there should be some justification for recommendations beyond the opinion of the experts on the team. At the very least, the Fund needs to distinguish between its official recommendations, which should be well grounded, and merely the opinions of the experts who happen to be on the team.

50. In the last few years, MCM has been moving to make the FSAP more efficient and to modernize the process. More attention is paid to pre-mission preparation, including a determination of the focal points of the assessment. In May 2018, management set a cap of six FTEs for FSAPs; this cap could release resources for voluntary non-S29 FSAPs or other bilateral financial surveillance activities. ${ }^{19}$ In light of the complaint that FSAP team members are not always well-prepared, it will be important to ensure that this target is not achieved by foisting more work on country authorities but rather by greater focus of the team's work.

51. The Fund is also developing its approach to stress testing (Anderson and others, 2018), including not just solvency tests of the banking sector, but also liquidity tests and more systemwide testing, in some cases using household surveys and corporate data.

52. Still, advanced economy authorities are at best mixed and mostly skeptical of the value added by the Fund's stress testing. Jeanne (2018) notes that regulatory authorities in a number of countries have moved to a more granular ("capillary"), bottom-up approach using data that in some countries cannot be shared with the Fund. The five-year horizon in most IMF stress tests was viewed to be onerous and artificial, seemingly tied to the periodicity of S29 assessments rather than a belief that the models yield any useful information at this time horizon. In contrast, many (but not all) developing and emerging countries seemed to gain significantly from the exercise, as the advanced countries had in the immediate aftermath of the crisis when the IMF was regarded externally as more of a leader in this area.

\footnotetext{
${ }^{19}$ In special circumstances, management may approve exceptions to this cap, such as for a first-time FSAP, the need for coverage of specific sector/issues that are critical for financial stability, and the size and complexity of the country's financial sector. Prior to this ceiling, the FSAPs for China $(2011,2017)$, the U.S. $(2010,2015)$, the U.K. (2016), Japan (2017), and Spain (2017) exceeded it.
} 


\section{Use of Market Indicators}

53. Although the FSAP is not carried out exclusively from a supervisory standpoint and is rooted in an analysis of balance sheet data, market-based indicators typically receive much less attention. ${ }^{20}$ This relative neglect stands in contrast to recent work by academics who have concluded that there is potentially significant informational value in market indicators. For example, Sarin and Summers (2016) employed a variety of market-based measures of banks' stock price volatility and implied volatility, beta, price-earnings ratios, out-of-the-money put option prices, credit default swap spreads and preferred stock prices, in an analysis which concluded that risks in 2016 were at least as high as in 2007 if not higher than in 2008, at least for the largest international banks and midsize U.S. banks. The authors posited that the primary factor behind this plight of the banking system is the decreased franchise value, which is an issue that has been highlighted in the GFSR.

54. Although low profitability has been picked up in several FSAPs as a risk (with the 2017 Netherlands FSAP being a good example), the review of FSSAs undertaken for this paper found that analysis of market indicators typically has received relatively brief attention. Basically, one comes away from most S29 FSAPs with the view that while there are risks and some regulatory fine-tuning to be done, the financial system looks much stronger than prior to the GFC-not surprising as this is the view of the regulatory community, and many working on FSAPs are part of that community. Sarin and Summers (2016) argue that financial systems are still very much at risk.

55. More generally, Sarin and Summers and many other economists doubt that the changes to the regulatory framework since the GFC have been sufficient to maintain financial stability. ${ }^{21}$ Although crises can be difficult to predict, as there are innumerable trigger events, financial fragility is easier to detect. Rising leverage ratios, rapid expansions of credit, asset price booms especially in combination with leverage, rising debt to equity ratios (or price to book value ratios) and dramatic signs of risk taking all are readily observable. ${ }^{22}$ Adrian and others (2018) look at leverage in relation to market size as a predictor of vulnerability, and Adrian and Brunnermeier (2016) propose a measure of systemic risk ( $\triangle \mathrm{CoVaR}$, the change in the value at risk on the financial system conditional on an institution being under duress relative to its median state) and show that it is

\footnotetext{
20 The FSAP's focus might reflect the view that the GFC itself was a result of the failure of market monitoring. However, as noted above and by Levine (2014), the crisis was at least as much a case of supervisory neglect.

${ }^{21}$ See Vickers (2017), which states: "The general opinion expressed by those in the financial sector and its regulators is that reform since 2008 has got us to about the right place in terms of limits on bank leverage. But the majority view of economists outside the financial sector is that Basel III goes nowhere near far enough."

22 Thus, so-called "Ninja" loans (those requiring no documentation of income, jobs or assets) not only were expanding rapidly before the 2008 crisis in the U.S., they had also been an important factor in the Savings and Loan crisis. To be sure, not all waves of increased speculation have had severe macro effects, though the absence of more severe effects (e.g., 1987 and 2000) likely were because of the macro policy response.
} 
predicted by leverage, size, maturity mismatch and asset booms. Abbassi and others (2017) examine credit risk connectedness, finding that banks' wholesale funding patterns and asset exposures affect their interdependence, and that market measures of interdependence provide a way to estimate these linkages even when more disaggregated balance sheet data are not available. More generally, researchers have been developing measures of credit risk, market and funding risk, and solvency and profitability risks of financial intermediaries and of their vulnerability to macro risks and interlinkages (e.g., Venditti and others, 2018).

56. While there is room for much more research in this area, there already is scope for FSAPs - and the Fund's financial surveillance more broadly - to make greater use of marketbased measures and public information to judge the safety and soundness of financial systems, especially for the high-income and emerging markets. This suggestion does not imply relying completely on market indicators, but it does mean more use of them than appears to be the case at present. ${ }^{23}$ For example, greater use of market indicators would allow a more continuous monitoring of risks and vulnerabilities. Relevant indicators could be identified in IMF monitoring, both in periodic FSAP and in intervening Article IV consultations.

\section{E. Topic Selection and New Issues}

57. An important question is whether FSAPs tend to be spread too thin rather than focusing on key risks. Experts inside and outside the IMF have suggested that in some FSAPs, topics that could become key to medium-term financial stability may receive less attention than those that are the focus of current discussion in policy making circles and the media (e.g., see Miles, 2018). For example, Borio (2018) argues that resource misallocation, which may have increased with a prolonged period of low interest rates, can contribute to delaying bank balance sheet adjustment by lowering the opportunity cost of holding bad loans and perhaps increasing the difficulty of distinguishing between more and less efficient uses of funds. Resource misallocation of course can also occur due to other factors, as when politically-motivated state-owned banks and/or directed credit programs grow in size. Misallocation can slow productivity and output growth, and in turn contribute to the adoption of costly policies. Yet it is difficult to find this concern in FSAPs, beyond the encouragement of asset quality reviews in Europe several years ago.

58. Another area that received little attention in some FSAPs is the coverage of operational risks. For example, Ariyoshi (2018) notes the omission in the FSAP of earthquake risk in Japan, notwithstanding the potentially devastating effects-financial, economic, human, environmental, etc.-were one to strike a large population center. Japan of course is not alone in its exposure to this risk. As with many operational risks, this one cannot be priced accurately, but financial institutions and exchanges can plan for how their systems and records will survive. They might

\footnotetext{
${ }^{23}$ IMF staff indicated that most FSAPs for economies with developed financial markets use market data - e.g., recent FSAPs for the Euro Area, U.S., China, Spain, New Zealand, Germany, U.K., Luxembourg, Ireland, Sweden, and Norway. They also pointed out that in most other countries, the availability and reliability of market indicators is very limited.
} 
have plans that might or might not need improvement, but readers of the FSAP will not discover whether that is the case or not.

59. Another issue that is rapidly affecting the financial systems of rich and poor countries alike-both financial institutions and exchanges around the world-is the impact of new emerging digital technologies. A particular concern relates to cyber risk, the electronic disruption of financial institutions and possibly financial networks, such as SWIFT. Demekas (2018) notes that cyber risk is an increasing concern of regulatory authorities that need to involve the intelligence community and private electronic security firms. Cyber risk, which has yet to lead to a systemic crisis, is just beginning to be explored in a few S29 FSAPs, though low-income countries, with limited expertise, might be the most vulnerable, and hacking is rapidly growing in sophistication. ${ }^{24}$ Indeed, as the IMF shapes its response, cyber risks are evolving too rapidly for countries to wait until their next FSAP to analyze their vulnerabilities.

60. New financial technology is yielding not just risks but pronounced benefits. Digital finance is already increasing the participation of many of the unbanked or underbanked in the financial systems of many countries (e.g., Kenya, India) and even is making the sighting of cash a rare phenomenon in others (Sweden). However, expanding financial access, as with any change in markets, involve risks as well. Banks and other intermediaries understandably do not want to be facing increased competition from other suppliers of payments services, and mobile money infrastructure also offers ways to market other financial services, which could be quite positive for users of financial services but disruptive to the suppliers. Although recent FSAPs have included qualitative discussions of cyber risks and the potential impact of fintech, this is an area that will need to get much more attention in the future particularly as fast-changing financial technology could become a risk to financial stability.

61. Digital or so-called cryptocurrencies, such as Bitcoin, Ethereum, and a wave of similar "coins" also are evolving and pose issues for finance, though at present do not appear to be likely to cause systemic issues. While issues around cryptocurrencies might be of concern in particular countries, the issues seem more in the domain of multilateral surveillance, such as the GFSR, rather than the FSAP.

62. An even more significant risk is related to global warming. A recent report of the Task Force on Climate-Related Financial Disclosures (TCFD), created by the FSB at the behest of G20 Finance Ministers, argued for a greater sense of urgency to shed light on the risks posed by climate change, both direct ones, such as increased severe weather-related events, as well as the indirect effects due to large relative price changes as the planet switches from brown to green technologies. TCFD (2017) recommended greater disclosure, especially on the part of financial intermediaries related to their governance (overseeing climate risks and opportunities); strategy

\footnotetext{
${ }^{24}$ See SWIFT warning, November 28, 2017, available at https://www.reuters.com/article/us-cyber-heistwarning/swift-warns-banks-on-cyber-heists-as-hack-sophistication-grows-idUSKBN1DT012.
} 
(the impact of climate change on businesses, strategy and planning); risk management (the process by which climate risks are identified, assessed, and managed); and metrics and targets (to assess risks and opportunities).

63. Banks and insurance companies are highly exposed to climate change by under-pricing the risks to their clients. Reducing uncertainty is one way to respond: getting more information on the climate-related risks to which financial institutions are exposed is a first step. ${ }^{25}$

64. Given the potential size of the risks, the FSAP would seem to offer an opportunity for discussions with authorities as to how they are coping with and planning for these risks, what policies are helping or hurting in the process, and then disseminating these views. Although climate change seems like a very long-term risk, the path according to the scientific community is relatively clear and adjustment costs will be smaller-even with a high discount rate- the sooner information-gathering and planning is begun.

\section{CONCLUSIONS AND RECOMMENDATIONS}

65. One of the often-overlooked factors behind the GFC (and many financial crises of recent decades) was the failure of regulators to implement rules and to use effectively the powers that they had. To the extent that the FSAP and more broadly financial surveillance by the IMF can keep the authorities "on their toes" and help disseminate information about risks, risk modelling and other practices related to financial system stability, it provides a useful check-up on national and global financial system stability. A regular and timely review of the key risks facing financial systems and what is being or can be done to strengthen the resilience of those systems falls entirely within the IMF's mandate. Moreover, the discipline of being assessed by a group of outsiders with deep knowledge of a variety of financial systems is an important contribution, in particular because domestic accountability of regulators generally is done by non-specialists. Legislative bodies cannot attract staff with sufficient expertise, nor are other government agencies successful in this regard (e.g., the U.S. General Accountability Office is constrained by civil service pay scales). Moreover, governments' attitudes towards regulation and its enforcement can fluctuate over time. Thus, the IMF can make an important contribution; the issue is how to maximize its value added.

66. The FSAP has become an increasingly sophisticated tool for evaluating the stability of financial systems and, for low- and middle-income countries (in conjunction with the World Bank), an important way to assess their developmental needs. But, at the same time, in response to the crisis and in part as a result of the IMF's significant technical assistance and training efforts, financial regulatory authorities have made great strides on their own and in some cases with IMF assistance. National authorities can and are dedicating orders of magnitude more time and effort to understanding the risks facing their systems and have access to more data,

${ }^{25}$ IMF staff notes that some FSAPs have pursued the issue of climate-related risks through analysis of insurers and reinsurers and, where relevant, have also assessed risks from energy prices in the context of stress testing. 
including proprietary information that in some cases cannot be legally shared. As a result, in many high-income and even middle-income countries officials report that the value added provided by the FSAP in terms of new analytical insights is relatively limited, even while IMF staff continue to see shortcomings in stress-testing frameworks used by many authorities, including in advanced economies.

67. The first recommendation concerns team preparation. In recent years MCM has significantly increased the amount of preparatory work preceding FSAP missions-a trend that should be reinforced including for consultants (many of whom reported not having sufficient preparation time). Greater preparation would ensure that team members were well-versed with current issues in the country concerned and the previous FSAP, and therefore making the best use of authorities' time. Preparation also provides the basis for greater attention to topic selection and prioritization, moving further towards a customized approach.

68. Second, work on preparation could be supported by fully-fledged and regular "off-site monitoring," especially for the countries with more systemically important financial sectorswhich also tend to be those with more information that is or can be made available online, as well as with market-based data. Offsite analysis has several advantages: it would allow staff to stay on top of significant risks; it can be used to prepare staff for mission work-so as to use their time and that of authorities most effectively; and it could be better used to decide on which countries need a closer look as part of the IMF's financial surveillance work, either by prioritizing a new FSAP or receiving emphasis in Article IV consultations. At the same time, maximizing the amount of work that can be done off-site could allow for a streamlined FSAP.

69. Third, FSAP and Article IV surveillance should be more closely integrated. There are many ways in which this could evolve in the longer term, but the immediate actions for the IMF are similar: greater tailoring of FSAPs to country circumstances and greater emphasis on financial and macrofinancial analysis in Article IV consultations, relying more heavily on the analysis and risks identified in FSAPs where available. We suggest two basic options for the longer term. Under the first option, the FSAP would maintain its current basic structure but would be more selective in its scope, including having different roles in stress-testing in countries with different local capacities. At the same time, Article IV surveillance would increase its focus on macrofinancial stability issues. Country case studies report that officials value the financial expertise on FSAP teams significantly more than that on Article IV teams, suggesting the need to further strengthen the latter. This is critical because even five-yearly FSAPs are too infrequent to detect fast changing risks, especially in countries where more than a decade can pass between FSAPs. Financial and macrofinancial Article IV surveillance would be rooted in, but not limited by, the previous FSAP exercise.

70. Under the second option, the responsibility for short-term financial stability work would be redirected to the Article IV consultation, providing more frequent in-depth surveillance over stability risks. This would require a very large increase in financial skills to Article IV teams: 2-4 staff with deep financial skills for countries with complex systems, and 1-2 added staff for less 
complex systems-implying a major shift in resources within the IMF. Also, country authorities would have to agree to longer and more resource intensive Article IV consultations. In any case, this option would need to be tried and assessed in a few countries on a pilot basis.

71. Under either approach, the FSAP could continue to be a useful tool to assess medium to longer term financial sector issues and would continue as a technical assistance tool for low- and some middle-income countries. ${ }^{26}$ This work would be organized around more institutional analysis of the structure, development, and efficiency of financial systems, and should address medium- to longer-term risks. Doing a periodic, lower frequency check of systems and processes-how the safety net is functioning, the efficiency of bank resolution and crisis management, structural financial sector issues that are influencing resource allocation, a review of regulatory gaps or weaknesses-would be a reasonable goal for an infrequent assessment (e.g., once a decade).

72. Fourth, the IMF should be more strategic in allocating FSAP resources, based on a broader expectation that participating in an FSAP would be a regular part of surveillance for more jurisdictions than the current S29, to include a broader range of economies with welldeveloped financial markets. Rather than coming up with a different static FSAP list, a more flexible approach is recommended. Under such an approach, the five or so financial sectors that are most systemically important would continue to be subject to a mandatory FSAP every five years, but with greater focus in coverage. The appropriate frequency for other jurisdictions would be determined according to a periodic assessment of systemic risk, interconnectedness and size, based in part on off-site monitoring. Under such an approach, FSAPs for many of the current S29 would be less frequent, freeing up resources for more frequent FSAPs in other jurisdictions that could have higher degrees of vulnerability.

73. Fifth, the Fund should consider some differentiation of its role in stress testing. Although stress testing should remain an important part of the Fund's financial sector surveillance, both the comments of advanced country authorities and the discussion in Jeanne (2018) suggest that some rethinking is needed. The Fund would need to devote significant additional resources to innovation in stress testing if it wants to remain relevant in the more advanced countries.

Alternatively, for the most advanced countries, the Fund should consider reviewing and advising the work of national regulators, ensuring that the stress tests are indeed stressful, assessing a suitable array of risks, and bringing the Fund's perspective on cross-border factors. Also, IMF staff should learn from advanced country regulators and disseminate advice and training to

\footnotetext{
${ }^{26}$ It may be possible to separate the surveillance and capacity building aspects of FSAPs. In 2016 the IMF launched a new demand-driven, donor-financed TA product, the Financial Sector Stability Review (FSSR) for lowand lower-middle-income countries. There were three FSSRs in 2016-17 and four were scheduled for 2018. FSSRs provide a baseline diagnostic review of authorities' capacity to undertake analysis related to financial stability and its institutional underpinnings, proposes medium-term reforms, and identifies priorities for TA. FSSRs covered topics such as banking supervision, securities markets, insurance and pensions, bank resolution and deposit insurance, monitoring of financial stability, financial stability issues under dollarization, and financial deepening and inclusion (e.g., Costa Rican FSSR). So far, FSSRs have been conducted without World Bank participation.
} 
others. In many other economies, where both data are more limited and skills are not at the frontier, IMF staff will need to continue to take the lead and actually do the testing as well as to continue to provide TA, which will also help maintain staff expertise in this area.

74. Sixth, the Fund's expertise in macrofinancial work needs to continue to be built up. IMF staff does not yet seem to have reached the point of delivering consistent excellence in macrofinancial surveillance. Moreover, truly cutting-edge financial sector work requires a depth of specialist expertise which does not appear to be easily compatible with the Fund's promotion and mobility schemes. As shown in Stedman (2018), it seems that incentives internally still favor becoming a macroeconomic generalist, which is consistent with authorities' views that the financial sector expertise of Article IV teams was not as strong as on FSAP teams. What type of role the Fund wishes to play must fit with the types of staff that it can attract, maintain, and dedicate to financial surveillance.

75. There are a few additional considerations that should be included in a reassessment or re-design of the FSAP. There is a lot of weight being placed on stress testing, but there is not yet strong evidence that current techniques are truly up to the task of safeguarding financial stability, as many of the models (both those used by the IMF and by authorities) have not been vetted in refereed journals, nor replicated and verified in subsequent research. Moreover, it remains to be seen whether the broader overhaul of the financial regulatory architecture will provide a sufficiently robust framework. While the IMF's role in setting international standards is discussed elsewhere in this evaluation (Cecchetti, 2018), it would seem relevant for FSAPs to pay more attention to whether international standards which are intended as a minimum provide adequate safeguards given national circumstances (see Miles, 2018).

76. Last, given the expense and importance of the issues covered in FSAPs, it would be useful for the Fund to actively encourage research on the FSAP process, most importantly by putting the publishable data together in an accessible form. For example, no one has done any research on the many different recommendations made by FSAPs because the overwhelming majority is buried in technical papers rather than summarized on a website. Allowing countries to benchmark their financial systems relative to others might also encourage their reform efforts, and accessible data would certainly encourage researchers inside and outside the Fund to use this information in publications in referred journals and for others to test and re-test the results. Independent, external empirical examination of the IMF approaches and recommendations would help identify needed modifications and enhance the credibility and traction of IMF advice. 
APPENDIX TABLE 1. JURISDICTIONS WITH SYSTEMICALLY IMPORTANT FINANCIAL SECTORS

\begin{tabular}{|lll|}
\hline Australia & Hong Kong SAR & Poland \\
Austria & India & Russian Federation \\
Belgium & Ireland & Singapore \\
Brazil & Italy & Spain \\
Canada & Japan & Sweden \\
China & Korea & Switzerland \\
Denmark & Luxembourg & Turkey \\
Finland & Mexico & United Kingdom \\
France & Netherlands & United States \\
Germany & Norway & \\
& & \\
& & \\
\hline Note: Countries in italics & & \\
\end{tabular}




\section{Appendix Table 2. Spain: Key Financial Stability Recommendations, 2017 (Near-term) ${ }^{1}$}

\section{To address crisis legacy and mitigate other risks to financial stability}

1 Enforce implementation of the ECB guidance on NPLs, including promoting banks' disclosure of targets and progress (paragraph 19)

2 Improve recovery of viable businesses by enabling the stay and involvement of public creditors in all pre-insolvency processes and enhancing the OCAP process for SMEs; strengthen commercial courts by resourcing them better (paragraph 21)

3 Evaluate the scope for further banking consolidation through mergers, branch reduction, and business model adjustments (paragraph 22)

4 Monitor rigorously interest rate and bond market risks; ensure appropriate capital requirements to mitigate such risks (paragraph 23)

$5 \quad$ Improve liquidity monitoring, including by closing reporting gaps; critically review funding structures and policies of banks with excessive reliance on ECB's liquidity support; overall, place a premium on effective liquidity risk management by banks (paragraph 23)

6 Initiate, supervisory and prudential steps to reduce the mismatching of assets/liabilities in insurer balance sheets (paragraph 24)

$7 \quad$ Foster development of market-based financing and supply of nonbank financial services for corporates and households (paragraph 25)

8 Enhance capacity to monitor and analyze macrofinancial linkages, intra-system connectedness and cross-border spillovers; close data gaps (paragraph 31)

9 Review, as a priority, Sareb's medium-term financial outlook based on adverse scenarios; set up a tripartite committee (BdE, MoE, and $\mathrm{FROB})$ to work out any needed mid-course corrections (paragraph 57)

\section{To strengthen systemic and prudential oversight}

10 Set up a "Systemic Risk Council" for inter-agency coordination on systemic risk factors, surveillance, and system-wide financial sector policies (paragraph 33)

$\mathrm{SSM}, \mathrm{BdE}$

MoE, MoJ

SSM, BdE

SSM, BdE

SSM, BdE

DGSyFP

MoE, BdE, CNMV, DGSyFP

BdE with CNMV and DGSyFP

MoE, BdE, FROB Expand the macroprudential toolkit to include borrower-based tools (paragraph 39)

MoE with BdE, CNMV, DGSyFP

$\begin{array}{ll}11 & \text { Expand the macroprudential toolkit to include borrower-based tools (paragraph } \\ 12 & \text { Increase supervisory focus on corporate governance practices across all credit }\end{array}$ institutions, and the nonbank sector (paragraphs 46, 51, 52)

All authorities

SSM, BdE, DGSyFP, CNMV

13 Assign the BdE full regulatory powers in matters not harmonized at the European level including authorizing mergers (paragraph 48)

\section{To bolster crisis management, resolution, and safety nets}

14 Develop a credible resolution strategy for credit cooperatives and other Less BdE, FROB, DGSyFP Significant Institutions (LSIs); prepare recovery and resolution plans for significant insurance companies (paragraphs 63-64)

15 Strengthen and upgrade the deposit guarantee scheme; create a protection scheme for insurance policyholders (paragraph 66)

${ }^{1}$ In addition, the FSSA also has several other recommendations. These are important and could follow after consideration has been given to the "near-term" recommendations in this table

Source: Reproduced from IMF (2017a). 
Appendix Table 3. China: Main Recommendations

\begin{tabular}{|c|c|}
\hline Recommendation & Priority ${ }^{1}$ \\
\hline \multicolumn{2}{|l|}{ Macroeconomic Recommendations } \\
\hline $\begin{array}{l}\text { De-emphasize high GDP growth projections in national plans that motivate setting high-growth } \\
\text { targets at the local level. ( }(45-47)\end{array}$ & H, NT \\
\hline \multicolumn{2}{|l|}{ Systemic Risk, Macroprudential Policy, and Strengthening Oversight } \\
\hline $\begin{array}{l}\text { Create a new Financial Stability Sub-Committee (FSS-C) with the sole functioning of preserving } \\
\text { financial stability ( }(\pi 55-58)\end{array}$ & $\mathrm{H}, \mathrm{NT}$ \\
\hline $\begin{array}{l}\text { Establish robust mechanisms for cooperation, coordination, and exchange of information- } \\
\text { including granular financial data—with domestic and foreign safety-net participants. ( }(139)\end{array}$ & $\mathrm{H}, \mathrm{NT}$ \\
\hline $\begin{array}{l}\text { Trigger the countercyclical capital buffer, and review banks' capital requirements with a view to a } \\
\text { targeted—and in some cases substantial—increase in capital. ( }(64, \text { Box } 6 \text { ) }\end{array}$ & $\mathrm{H}, \mathrm{NT}$ \\
\hline $\begin{array}{l}\text { Amend primary laws to strengthen operational and budgetary autonomy of the People's Bank of } \\
\text { China }(\mathrm{PBC}) \text { and the regulatory agencies, and increase their resources. ( }(162)\end{array}$ & $\mathrm{H}, \mathrm{MT}$ \\
\hline $\begin{array}{l}\text { Address data gaps that impede systemic risk monitoring and effective financial regulation and } \\
\text { supervision. ( }(21, \text { Box } 5 \text { ) }\end{array}$ & $\mathrm{H}, \mathrm{MT}$ \\
\hline $\begin{array}{l}\text { Review purpose and structure of the PBC's macroprudential assessment (MPA) with a view to } \\
\text { simplifying, and use it solely as an input to the deliberations of the FSS-C and its working-level } \\
\text { sub-groups. (Box 5) }\end{array}$ & M \\
\hline \multicolumn{2}{|l|}{ Regulation and Supervision: Banks } \\
\hline $\begin{array}{l}\text { Enhance group risk supervision and the ability to supervise banking and wider financial groups, as } \\
\text { well as ownership structures, including the identification of ultimate beneficial owners ( }(\pi 76-78)\end{array}$ & $\mathrm{H}, \mathrm{MT}$ \\
\hline $\begin{array}{l}\text { Eliminate the use of collateral in loan classification, constrain banks' ability to roll-over credit to } \\
\text { non-small and medium enterprise corporate borrowers, and classify all loans overdue by more } \\
\text { than } 90 \text { days as nonperforming. ( }(\pi 80)\end{array}$ & $\mathrm{H}, \mathrm{MT}$ \\
\hline Strengthen enforcement of the "look-through" principle. ( $(21$, Box 6) & M \\
\hline $\begin{array}{l}\text { Increase liquidity coverage ratio (LCR) coverage for interbank products and for off-balance sheet } \\
\text { Wealth Management Products (WMPs). ( }(699)\end{array}$ & M \\
\hline $\begin{array}{l}\text { Enhance regulatory reporting requirements to collect more granular supervisory data on banks' } \\
\text { investment holdings and provisioning. ( }(79)\end{array}$ & M \\
\hline $\begin{array}{l}\text { The China Banking Regulatory Commission (CBRC) should enhance forward-looking integrated risk } \\
\text { analysis to identify vulnerabilities, challenge banks, and facilitate ex ante intervention. ( }(1103)\end{array}$ & M \\
\hline \multicolumn{2}{|l|}{ Stress Testing } \\
\hline $\begin{array}{l}\text { Substantially enhance and systematize data and information sharing across the three regulatory } \\
\text { agencies and the PBC for stress testing and systemic risk assessment purposes. Use more granular } \\
\text { supervisory data in stress tests. ( }(\pi 59)\end{array}$ & $\mathrm{H}, \mathrm{MT}$ \\
\hline $\begin{array}{l}\text { Expand the coverage of nonbanks and interconnections significantly for systemic risk assessment, } \\
\text { developing and integrating stress testing of collective investment schemes (CIS). ( }(159)\end{array}$ & M \\
\hline Enhance inter-agency coordination and analytical capacity of the stress testing teams. ( $(60)$ & M \\
\hline \multicolumn{2}{|l|}{ Shadow Banking and Implicit Guarantees } \\
\hline $\begin{array}{l}\text { Make legal and regulatory changes to ensure the bankruptcy remoteness of CIS, including WMPs, } \\
\text { in the event of insolvency of the manager or the custodian. ( }(68)\end{array}$ & $\mathrm{H}, \mathrm{MT}$ \\
\hline $\begin{array}{l}\text { Move toward eliminating limits on lending to specific sectors, conditional on eliminating implicit } \\
\text { guarantees. ( }(67)\end{array}$ & $M$ \\
\hline $\begin{array}{l}\text { Interventions in asset markets, including housing and the equity market, should be limited to } \\
\text { episodes of systemic risk. ( (IBox 4) }\end{array}$ & $M$ \\
\hline
\end{tabular}




\begin{tabular}{|c|c|}
\hline Recommendations & Priority 1 \\
\hline \multicolumn{2}{|l|}{ Regulation and Supervision: Securities Markets } \\
\hline Improve disclosure of CIS; prohibit specifying expected returns in the prospectus of WMPs. ( $(\pi 2)$ & $\mathrm{H}, \mathrm{NT}$ \\
\hline $\begin{array}{l}\text { Introduce a functional overlay to supervision to ensure that similar products issued by differing } \\
\text { financial firms are supervised and regulated similarly. }(\$ 50,62)\end{array}$ & $\mathrm{H}, \mathrm{MT}$ \\
\hline Tighten eligibility and enhance haircut methodology for repo collateral. (I71) & M \\
\hline $\begin{array}{l}\text { Strengthen systemic risk monitoring mechanisms to ensure a holistic view of securities markets } \\
\text { and their financial sector interconnectedness. ( }(184)\end{array}$ & M \\
\hline \multicolumn{2}{|l|}{ Regulation and Supervision: Insurance } \\
\hline $\begin{array}{l}\text { Develop plans for risk-based supervision, bringing together all issues and actions of each insurer, } \\
\text { including market conduct. ( }(188)\end{array}$ & M \\
\hline Establish a plan to move valuation to a more market-consistent basis. ( $(88)$ & M \\
\hline \multicolumn{2}{|l|}{ Supervision of Financial FMIs } \\
\hline $\begin{array}{l}\text { Adopt full delivery-versus-payment in the China Securities Depository and Clearing Corporation } \\
\text { (CSDC). (आ90) }\end{array}$ & $\mathrm{H}, \mathrm{NT}$ \\
\hline $\begin{array}{l}\text { Strengthen resilience of financial market infrastructures (FMIs) through: full implementation of the } \\
\text { CPSS-IOSCO Principles; and strengthening of the legal framework ( }(90-92)\end{array}$ & $\mathrm{H}, \mathrm{MT}$ \\
\hline $\begin{array}{l}\text { Expand provision of central bank services to all systemically-important central counterparties } \\
\text { (CCPs). ( (\$94) }\end{array}$ & M \\
\hline \multicolumn{2}{|l|}{ AML/CFT } \\
\hline $\begin{array}{l}\text { Mandate enhanced customer due diligence (CDD) for domestic politically-exposed persons on a } \\
\text { risk sensitive basis. ( }(98)\end{array}$ & M \\
\hline $\begin{array}{l}\text { Ensure that self-laundering is more effectively investigated and prosecuted as a stand-alone } \\
\text { offense. ( }(98)\end{array}$ & M \\
\hline \multicolumn{2}{|l|}{ Crisis Management } \\
\hline $\begin{array}{l}\text { Triggers for activating a government-led crisis response should be more clear and defined, and } \\
\text { limited to systematic cases that may require public resources. ( }(102)\end{array}$ & H, NT \\
\hline $\begin{array}{l}\text { Develop a special resolution regime for banks and systematically important insurance companies. } \\
(\pi 106)\end{array}$ & $\mathrm{H}, \mathrm{MT}$ \\
\hline Develop a formal framework for emergency liquidity assistance by the PBC. (โ109) & $\mathrm{H}, \mathrm{MT}$ \\
\hline Enhance the design of the protection funds to limit moral hazard. (₫107-108) & M \\
\hline \multicolumn{2}{|l|}{ Financial Inclusion } \\
\hline Enhance the legal, regulatory, and supervisory frameworks for fintech. ( $(117)$ & M \\
\hline
\end{tabular}


ApPendix TABle 4. Risk AsSesSment AND StRess TeSting: SPAIN, 2012 AND 2017

\begin{tabular}{|c|c|c|}
\hline FSSA & 2012 & 2017 \\
\hline Risk matrix & $\begin{array}{l}\text { - Continued weak growth and high } \\
\text { unemployment } \\
\text { - Intensification of the decline in real estate prices } \\
\text { - Spillovers: Deteriorating Euro Area growth and } \\
\text { worsening of Eurozone crisis } \\
\text { - Difficulty in meeting banks' refinancing needs }\end{array}$ & $\begin{array}{l}\text { - Weak economic growth due to internal and } \\
\text { external factors } \\
\text { - Tighter and more volatile global financial } \\
\text { conditions } \\
\text { - Significant growth deterioration in countries } \\
\text { with a large presence of Spanish banks }\end{array}$ \\
\hline Solvency test - scenarios & $\begin{array}{l}\text { 1. Baseline growth projections are consistent with } \\
\text { the IMF's World Economic Outlook Update } \\
\text { (January 2012), while the adverse scenarios } \\
\text { comprise: } \\
\text { 2. A "double-dip" recession scenario of one } \\
\text { standard deviation from the baseline GDP } \\
\text { growth trend over the two-year horizon ("IMF } \\
\text { adverse"). In this scenario, most of the shock to } \\
\text { economic growth occurs in the first year } \\
\text { resulting from a sharp decline in output, further } \\
\text { declines in house prices close to levels observed } \\
\text { in } 2002 \text {, and rising unemployment. Although the } \\
\text { cumulative GDP shock under this scenario of } \\
5.7 \text { percentage points would be extreme by } \\
\text { historical standards, it represents a plausible tail } \\
\text { risk under current circumstances. } \\
\text { 3. An alternative adverse scenario ("BdE adverse") } \\
\text { where the shock to the two-year real GDP } \\
\text { growth is more modest (i.e., reduced by } 2.5 \\
\text { percentage points relative to the "IMF adverse" } \\
\text { scenario. }\end{array}$ & $\begin{array}{l}\text { 1. "Baseline Scenario" based on the IMF } \\
\text { October } 2016 \text { or January } 2017 \text { Update World } \\
\text { Economic Outlook. while the adverse scenarios } \\
\text { comprise: } \\
\text { Scenario 1: Financial stress in Europe } \\
\text { - Assumes the realization of financial stability } \\
\text { risks in the Euro Area with spillovers } \\
\text { worldwide. } \\
\text { - Includes an abrupt unwinding of financial } \\
\text { risk taking and low secondary market } \\
\text { liquidity in systemic advanced economies. } \\
\text { - Assumes a reemergence of financial stress } \\
\text { in high spread Euro Area economies, } \\
\text { represented by an increase (and } \\
\text { divergence) in long-term government bond } \\
\text { yields and stock-market sell-off. } \\
\text { Shocks include: } \\
\text { - A tightening of financial conditions in } \\
\text { systemic economies, represented by risk } \\
\text { premium shocks and increases in long-term } \\
\text { yields; A credit cycle downturn in all } \\
\text { emerging market economies and a } \\
\text { term. } \\
\text { disorderly deleveraging in China, } \\
\text { represented by an increase in default rate } \\
\text { on bank loans; suppressed economic risk } \\
\text { taking worldwide, with private investment } \\
\text { and private consumption declining in all } \\
\text { economies; Additional contraction in } \\
\text { consumption and investment in Spain. } \\
\text { Scenario 2: De-globalization and } \\
\text { Stagnation in Advanced Economies: } \\
\text { in the medium-term. } \\
\text { term, and their dampening effect on growth } \\
\text { Sources of shocks: } \\
\text { - }\end{array}$ \\
\hline
\end{tabular}




\begin{tabular}{|c|c|c|}
\hline FSSA & 2012 & 2017 \\
\hline & & $\begin{array}{l}\text { - Secular stagnation in the medium-term due } \\
\text { to protectionist measures in Europe and the } \\
\text { United States. } \\
\text { - Large capital outflows from emerging } \\
\text { markets. } \\
\text { - Additional demand shocks in those } \\
\text { countries with a significant Spanish bank } \\
\text { presence. } \\
\text { - Political uncertainty and roll back of reforms } \\
\text { hit confidence and affect bond yields in } \\
\text { Spain. Spain suffers additional pressure on } \\
\text { public finances and an aggregate demand } \\
\text { shock. }\end{array}$ \\
\hline Liquidity risk & $\begin{array}{l}\text { Implied Cash Flow Tests } \\
\text { - 5-day test: Consecutive outflow of liabilities over } \\
\text { five days } \\
\text { - } 30 \text {-day test: One-off aggregate outflow of } \\
\text { liabilities for } 30 \text { days. } \\
\text { Proposed Basel III Standard Measures } \\
\text { - Liquidity Coverage Ratio (LCR): short-term } \\
\text { resilience to potential liquidity disruptions Stock } \\
\text { of high-quality liquid assets would need to cover } \\
\text { 30-day net cash outflows } \\
\text { - Net Stable Funding Ratio (NSFR): long-term } \\
\text { structural ratio to address liquidity mismatches. } \\
\text { The amount of available stable funding to } \\
\text { exceed the level of required funding. }\end{array}$ & $\begin{array}{l}\text { - An extended Basel III LCR scenario with } \\
\text { variants (retail/wholesale shock). } \\
\text { - A Basel III NSFR scenario. } \\
\text { - A cash-flow based scenario analyzing } \\
\text { different maturity buckets. }\end{array}$ \\
\hline $\begin{array}{l}\text { Spillover Risk into the } \\
\text { Domestic Banking System }\end{array}$ & $\begin{array}{l}\text { The methodology is based on Espinosa-Vega and } \\
\text { Sole (2010); it assumes the manifestation of } \\
\text { extreme tail risks (i.e., the failure of the banking } \\
\text { system of a country) and illustrates the relative } \\
\text { importance of systemic linkages across countries } \\
\text { through the global banking network. Spillovers are } \\
\text { modeled by (i) estimating the "domino effects" } \\
\text { triggered by the default of a banking system's } \\
\text { interbank obligations (credit shock); (ii) looking at } \\
\text { the effects of a credit-plus-funding event, where } \\
\text { the default of a banking system also leads to a } \\
\text { liquidity squeeze for those countries exposed to } \\
\text { funding from the defaulting system (i.e., the credit } \\
\text { shock is compounded by a funding shock and } \\
\text { associated fire sale losses). }\end{array}$ & $\begin{array}{l}\text { Cross-border analysis } \\
\text { Espinoza-Vega and Sole (2010) methodology } \\
\text { Diebold and Yilmaz (2014) methodology } \\
\text { The Global VAR (2007) met } \\
\text { Interbank market analysis } \\
\text { Espinoza-Vega and Sole (2010) methodology } \\
\text { Cross-sector analysis } \\
\text { Diebold and Yilmaz (2014) methodology }\end{array}$ \\
\hline
\end{tabular}

Sources: IMF (2012) and Related Documents; IMF, (2017a) and Related Documents. 
ApPendix TABle 5. RISK ANAlysis AND StReSS TeSting: GeRmany, 2011 AND 2016

\begin{tabular}{|c|c|c|}
\hline FSSA & 2011 & 2016 \\
\hline Risk matrix & $\begin{array}{l}\text { 1. Sharp "double dip" recession. } \\
\text { 2. Very slow growth in Europe and low interest } \\
\text { rates. } \\
\text { 3. Sustained high sovereign risk. } \\
\text { 4. Regulatory uncertainty and regulatory } \\
\text { burden. }\end{array}$ & $\begin{array}{l}\text { 1. Protracted period of slower growth in key } \\
\text { advanced economies and sharp downturn in China } \\
\text { and other EMs, leading to slowdown of external } \\
\text { demand and dampening of global growth } \\
\text { 2. Reemergence of EA sovereign bond market } \\
\text { volatility and peripheral sovereign contagion. } \\
\text { Financial stress in the Euro Area could re-emerge } \\
\text { triggered by policy uncertainty, faltering reforms, } \\
\text { or political unrest. } \\
\text { 3. Excessive risk-taking associated with the low } \\
\text { interest rate environment. } \\
\text { 4. Distress in a major financial institution }\end{array}$ \\
\hline Solvency test - scenarios & $\begin{array}{l}\text { - Baseline: October } 2010 \text { WEO projections for } \\
\text { key macrofinancial variables (GDP growth } \\
\text { and interest rates). } \\
\text { - Scenario 1: Double Dip: } 2 \text { standard } \\
\text { deviations (SD) GDP decline with respect to } \\
\text { baseline (maximum } 5.4 \text { percentage point } \\
\text { deviation), and spike in short-term interest } \\
\text { rates. } \\
\text { - Scenario 2: Slow Growth scenario } \\
\text { (cumulative } 4.0 \text { percentage point deviation). } \\
\text { - Scenario } 3 \text { ("supplementary" stress test): } 2.6 \\
\text { SD with respect to baseline. } \\
\text { - Sensitivity analysis: up to } 50 \text { percent increase } \\
\text { in loss rates, default of three largest } \\
\text { borrowers. }\end{array}$ & $\begin{array}{l}\text { 1. The October WEO forecasts constitutes the } \\
\text { baseline scenario. } \\
\text { 2. The "Global Stress Scenario" features } \\
\text { - a serious recession, triggered by a tightening of } \\
\text { global financial conditions, accompanied by credit } \\
\text { cycle downturns in emerging economies; } \\
\text { - realization of financial stability risks delays or stalls } \\
\text { monetary normalization in the systemic advanced } \\
\text { economies, including an abrupt decompression of } \\
\text { asset risk premia relative to the baseline; } \\
\text { - secondary market liquidity drops in all of the } \\
\text { systemic advanced economies as financial risk } \\
\text { taking unwinds. } \\
\text { - credit cycle downturn in emerging economies, } \\
\text { accompanied by a disorderly deleveraging in } \\
\text { China, and suppressed economic risk-taking } \\
\text { worldwide. Substantial drop in private domestic } \\
\text { demand induced by negative investment and } \\
\text { consumption demand shocks, representing a loss } \\
\text { in confidence by nonfinancial corporates and } \\
\text { households, which raise their saving rates and } \\
\text { delay expenditures. Both weigh heavily on } \\
\text { aggregate demand. } \\
\text { - House prices decline by } 10 \text { percent over three } \\
\text { years vis-à-vis the starting point. } \\
\text { - Over two (three) years, the scenario constitutes a } \\
\text { shock to real annual GDP growth equaling } 3.8 \\
\text { standard deviations ( } 3.2 \text { standard deviations). } \\
\text { ine "Euro Area Crisis Scenario" } \\
\text { in } 2011 \text {-2013, induced by a collapse of financial risk } \\
\text { taking, a complete dry-up of secondary market } \\
\text { liquidity throughout the Euro Area, and renewed } \\
\text { financial stress in the Euro Area periphery, } \\
\text { represented by the divergence of long-term } \\
\text { government bond yields between the periphery, } \\
\text { where they rise by } 100 \text { basis points more during } \\
\text { points and the core, where they rise by } 50 \text { basis } \\
\text { - }\end{array}$ \\
\hline
\end{tabular}




\begin{tabular}{|c|c|c|}
\hline FSSA & 2011 & 2016 \\
\hline & & $\begin{array}{l}\text { - a pro-cyclical expenditure-based fiscal } \\
\text { consolidation reaction in the Euro Area periphery } \\
\text { to public debt sustainability concerns there, which } \\
\text { raises the primary fiscal balance ratio by } 2 \\
\text { percentage points during } 2016 \text { and } 2017 \\
\text { - a massive selloff in stock markets due to generally } \\
\text { lower risk appetite, and substantial investor } \\
\text { sentiment shocks. } \\
\text { - Consistent with that, house prices decline by } 10 \\
\text { percent over three years vis-à-vis the starting } \\
\text { point. } \\
\text { Sensitivity analysis } \\
\text { - Scenario } 3:+200 \text { basis point parallel shift (increase) } \\
\text { as of December } 2014 \text { yield curve } \\
\text { - Scenario } 4:-100 \text { basis points parallel shift (drop) in } \\
\text { yield curve as of December 2014, without } \\
\text { behavioral response (i.e., static) }\end{array}$ \\
\hline Liquidity stress test & $\begin{array}{l}\text { Liquidity Stress Tests } \\
\text { Implied Cash Flow Tests: Cumulative outflow of } \\
\text { about } 60 \text { percent of wholesale funding and } 15 \\
\text { percent of customer deposits. } \\
\text { Supplementary test: foreseen Basel III ratios. }\end{array}$ & $\begin{array}{l}\text { Top-down: cash-flow-based, short-term liquidity } \\
\text { stress test, assessing resilience to multifactor } \\
\text { scenario. This analysis constitutes an approximation } \\
\text { of banks' CRD IV Liquidity Coverage Ratio (LCR), } \\
\text { using supervisory and regulatory reporting data. }\end{array}$ \\
\hline $\begin{array}{l}\text { Spillover Risk into the } \\
\text { Domestic Banking System }\end{array}$ & $\begin{array}{l}\text { Two approaches to stress testing banks' } \\
\text { solvency were adopted (a) a bank-by bank } \\
\text { balance sheet approach; and (b) a market- } \\
\text { based systemic approach. The two methods } \\
\text { complement each other, allowing for a } \\
\text { comprehensive coverage of the German } \\
\text { banking system on the one hand and } \\
\text { the incorporation of spillover } \\
\text { effects/contagion on the other. Solvency } \\
\text { stress test include: Risks comprised credit risk, } \\
\text { including counterparty credit risk; market risk; } \\
\text { operational risk; and explicit simulation of } \\
\text { contagion/spillovers risks (captured by the } \\
\text { systemic CCA). }\end{array}$ & $\begin{array}{l}\text { The FSAP team applies two main approaches to } \\
\text { examine interconnectedness and contagion, based } \\
\text { on cross border exposure and market data: } \\
\text { Espinoza-Vega and Sole (2010) methodology } \\
\text { - Examine cross-border banking sector exposures, } \\
\text { using the BIS consolidated banking statistics ( } 2015 \\
\text { Q1) and regulatory capital data from FSI. } \\
\text { - Positions include aggregated bilateral banking and } \\
\text { total exposures (bank, non-bank private sector and } \\
\text { public). } \\
\text { - Consider both initial credit and funding shocks to } \\
\text { the banking sector. } \\
\text { Diebold and Yilmaz (2014) methodology } \\
\text { Analysis } 1 \text { : Bank and insurance linkages within } \\
\text { Germany } \\
\text { - Examine the spillover risks among publicly listed } \\
\text { German bank and insurance companies } \\
\text { - Use daily equity returns data from } 16 \text { July } 2015 \text { to } \\
23 \text { February } 2016 \text { for publicly listed German banks } \\
\text { and insurers. } \\
\text { - Interconnectedness measure is derived from the } \\
\text { variance decomposition of the VAR } \\
\text { Analysis 2: Interlinkages among Deutsche Bank, } \\
\text { Commerzbank and GSIBs } \\
\text { - Examine the spillover risks among Deutsche Bank, } \\
\text { Commerzbank and other GSIBs } \\
\text { - Use daily equity returns data from } 11 \text { October } 2007 \\
\text { to } 26 \text { February } 2016 \text { for systemically important } \\
\text { international banks. }\end{array}$ \\
\hline
\end{tabular}




\begin{tabular}{|c|c|c|}
\hline FSSA & 2011 & 2016 \\
\hline Insurance stress test & $\begin{array}{l}\text { Microprudential stress tests for all German } \\
\text { insurers are regularly carried out under BaFin's } \\
\text { guidance, while Bundesbank is analyzing the } \\
\text { sector's risk from a topdown perspective. Ad } \\
\text { hoc tests are run, for example, on the effects of } \\
\text { low interest rates. The tests assess the } \\
\text { potential reduction of the value of the assets } \\
\text { under stress, accounting for asset price risks } \\
\text { and credit risk. On the liability side, the } \\
\text { solvency requirements according to Solvency I } \\
\text { are used as a buffer against technical } \\
\text { provisions. Estimates account for the growth of } \\
\text { business, risk mitigations, hidden reserves, and } \\
\text { specific insurer risk elements (for example, free } \\
\text { provisions for bonuses and rebates). }\end{array}$ & $\begin{array}{l}\text { Solvency II Standard Formula } \\
\text { Scenario analysis } \\
\text { One in } 200 \text { years event using Solvency II parameters } \\
\text { as a basis, including: } \\
\text { - A } 4.5 \text { to } 37.5 \text { percent haircut of corporate bonds } \\
\text { (with 5-year maturity) }\end{array}$ \\
\hline
\end{tabular}




\section{REFERENCES}

Abbassi, Puriya, and others, 2017, "Credit risk interconnectedness: What does the market really know?" Journal of Financial Stability, Vol. 29, April, 1-12.

Adrian, Tobias, Karol Jan Borowiecki, and Alexander Tepper, 2018, "A Leverage-Based Measure of Financial Stability," Discussion Papers on Business and Economics, University of Southern Denmark, No. 1/2018.

Adrian, Tobias, and Markus Brunnermeier, 2016, "CoVaR," American Economic Review, Vol. 106, No. 7, July, 1705-1741.

Akerlof, George, and Paul Romer, 1993, "Looting: The Economic Underworld of Bankruptcy for Profit, Brookings Papers on Economic Activity, Vol. 1993, No. 2, 1-73.

Anderson, Jeffrey, 2018, "IMF Financial Surveillance of Germany," Chapter 2 in "IMF Financial Surveillance in Action: Country Case Studies from Europe and Sub-Saharan Africa," IEO Background Paper No. BP/18-02/09 (Washington: International Monetary Fund). 2018, "IMF Financial Surveillance of Italy," Chapter 3 in "IMF Financial Surveillance in Action: Country Case Studies from Europe and Sub-Saharan Africa," IEO Background Paper No. BP/18-02/09 (Washington: International Monetary Fund).

Anderson, Ron, and others, 2018, "Macroprudential Stress Tests and Policies: Stretching for Robust and Implementable Frameworks," Joint IMF and LSE Report (London: Systemic Risk Centre, London School of Economics and Political Science). Available at http://www.systemicrisk.ac.uk/publications/stress-tests.

Ariyoshi, Akira, 2018, "IMF Financial Surveillance of Japan," Chapter 3 in "IMF Financial Surveillance in Action: Country Case Studies from Asia and the Western Hemisphere," IEO Background Paper No. BP/18-02/10 (Washington: International Monetary Fund).

Barth, James, Gerard Caprio, and Ross Levine, 2012, Guardians of Finance: Making Regulators Work for Us (Cambridge, MA: MIT Press).

Basel Committee on Banking Supervision, 2017, "Supervisory and bank stress testing: range of practices" (Basel: Bank for International Settlements), December. Available at https://www.bis.org/bcbs/publ/d427.htm.

Bebchuk, Lucian, Alma Cohen, and Holger Spamann, 2010, "The Wages of Failure: Executive Compensation at Bear Stearns and Lehman 2000-2008," Yale Journal on Regulation, 27, 257-282. 
Borio, Claudio, 2018, "A blind spot in today's macroeconomics?" Panel remarks at BIS-IMF-OECD Joint Conference on "Weak productivity: the role of financial factors and policies" (Basel: Banking for International Settlements), January 10-11. Available at https://www.bis.org/speeches/sp180110.pdf.

and William White, 2004, "Whither monetary and financial stability? the implications of evolving policy regimes," BIS Working Papers No. 147 (Basel: Bank for International Settlements).

Braxton Little, Jane, 2009, "The Ogallala Aquifer: Saving a Vital U.S. Water Source," Scientific American, March 1.

Caprio, Gerard, 2011, "Macrofinancial Linkages in IMF Research," IEO Background Paper No. BP/11/07 (Washington: International Monetary Fund).

2014, "Financial Regulation after the Crisis: How Did We Get Here, and How Do We Get Out?" in Reuven Glick and Mark Spiegel, eds., "Prospects for Asia and the Global Economy," Asia Economic Policy Conference Proceedings. Available at http://www.frbsf.org/economic-research/events/2013/november/asia-economic-policyconference/.

Cecchetti, Stephen, 2018, "Collaboration in Financial Regulatory Reform: The IMF, the Financial Stability Board, and the Standard Setting Bodies," IEO Background Paper No. BP/1802/04 (Washington: International Monetary Fund).

Cheong, Latifah Merican, 2018, "IMF Financial Surveillance in Malaysia, Singapore, and Thailand," Chapter 4 in "IMF Financial Surveillance in Action: Country Case Studies from Asia and the Western Hemisphere," IEO Background Paper No. BP/18-02/10 (Washington: International Monetary Fund).

Danielsson, Jon, and others, 2001, "An Academic Response to Basel II," LSE Financial Markets Group, Special Paper No. 130.

de Bolle, Monica, 2018, "IMF Financial Surveillance of Mexico," Chapter 5 in "IMF Financial Surveillance in Action: Country Case Studies from Asia and the Western Hemisphere," IEO Background Paper No. BP/18-02/10 (Washington: International Monetary Fund)

Demekas, Dimitri, 2018, "Emerging Technology-Related Issues in Finance and the Fund: A Stocktaking," IEO Background Paper No. BP/18-02/07 (Washington: International Monetary Fund).

Dollar, David, 2018, "IMF Financial Surveillance of China," Chapter 2 in "IMF Financial Surveillance in Action: Country Case Studies from Asia and the Western Hemisphere," IEO Background Paper No. BP/18-02/10 (Washington: International Monetary Fund). 
Georgescu, Oana-Maria, and others, 2017, "Do stress tests matter? Evidence from the 2014 and 2016 stress tests," European Central Bank Working Paper Series No. 2054, May.

Goldstein, Morris, 2017, Banking's Final Exam: Stress Testing and Bank-Capital Reform, Policy Analyses in International Economics 106 (Washington: Peterson Institute for International Economics), May.

Independent Evaluation Office of the International Monetary Fund (IEO), 2006, Financial Sector Assessment Program (Washington: International Monetary Fund).

Independent Evaluation Office of the International Monetary Fund (IEO), 2011, IMF Performance in the Run-up to the Financial and Economic Crisis: IMF Surveillance in 2004-07 (Washington: International Monetary Fund). 2014, IMF Response to the Financial and Economic Crisis (Washington: International Monetary Fund). ,2016, The IMF and the Crises in Greece, Ireland, and Portugal (Washington: International Monetary Fund).

International Monetary Fund, 2006a, "Ireland: Financial System Stability Assessment Update," IMF Country Report No. 06/292, August (Washington). ,2006b, "Spain: Financial System Stability Assessment, including Reports on the Observance of Standards and Codes on the following topics: Banking Supervision, Insurance Supervision, Securities Supervision, Payment Systems, Securities Settlement Systems, and Financial Policy Transparency," IMF Country Report No. 06/212, June (Washington). ,2008, "Iceland: Financial System Stability Assessment-Update" IMF Country Report No. 08/368, August (Washington). , 2010, "Integrating Stability Assessments Under the Financial Sector Assessment Program into Article IV Surveillance," August (Washington).

2011, "Germany: Financial System Stability Assessment," IMF Country Report No. 11/169 (Washington).

2012, "Spain: Financial System Stability Assessment," IMF Country Report No. 12/137 (Washington).

2013, "Italy: Financial System Stability Assessment," IMF Country Report No 13/300, September (Washington). 
,2014a, Global Financial Stability Report-Moving from Liquidity- to Growth-Driven Markets, April (Washington).

2014b, "Review of the Financial Sector Assessment Program: Further Adaptation to the Post Crisis Era," September (Washington).

,2014c, "Triennial Surveillance Review," October (Washington).

2016a, "Germany: Financial Sector Assessment Program—Financial System Stability Assessment," IMF Country Report No. 16/189 (Washington).

2016b, Global Financial Stability Report-Fostering Stability in a Low-Growth, Low-Rate Era, October (Washington).

, 2017a, "Spain: Financial System Stability Assessment" IMF Country Report No. 17/321, October (Washington).

2017b, Zambia: Financial System Stability Assessment, IMF Country Report 17/349, November (Washington).

2017c, "People's Republic of China: Financial System Stability Assessment-Press Release and Statement by the Executive Director for People's Republic of China" IMF Country Report No. 17/358, December (Washington).

2017d, "India: Financial System Stability Assessment-Press Release and Statement by the Executive Director for India," IMF Country Report 17/390, December (Washington).

,2017, Kingdom of the Netherlands: Financial System Stability Assessment, Technical Note-Financial Stability and Stress Testing of the Banking, Household and Corporate Sectors, IMF Country Report 17/95 (Washington). and The World Bank, 2009, "The Financial Sector Assessment Program After 10 Years: Experience and Reforms for the Next Decade," August 28 (Washington).

Jeanne, Olivier, 2018, "Analytical Frameworks and Toolkits in IMF Financial Surveillance," IEO Background Paper No. BP/18-02/06 (Washington: International Monetary Fund).

Johnson, Simon and James Kwak, 2010, 13 Bankers: The Wall Street Takeover and the Next Financial Meltdown (New York: Vintage Books).

Kellermann, Thomas, 2017, "Follow the Money: Civilizing the Darkweb Economy," Digital Futures Project (Washington: The Wilson Center).

Kopp, Emanuel, 2015. "Design and Quality Assessment of Bottom Up Stress Tests," IMF Guidance Notes on Stress Tests, GN\#10. 
Levine, Ross, 2014, "Aspects of IMF Financial Sector Surveillance During the Crisis," IEO Background Paper No. BP/14/08 (Washington: Monetary Fund).

Miles, David, 2018, "IMF Financial Surveillance of the United Kingdom," Chapter 4 in "IMF Financial Surveillance in Action: Country Case Studies from Europe and Sub-Saharan Africa," IEO Background Paper No. BP/18-02/09 (Washington: International Monetary Fund).

Murray, John, 2018, "IMF Financial Surveillance of the United States," Chapter 6 in "IMF Financial Surveillance in Action: Country Case Studies from Asia and the Western Hemisphere," IEO Background Paper No. BP/18-02/10 (Washington: International Monetary Fund).

Ncube, Mthuli, 2018, "IMF Financial Surveillance of Ghana, Kenya, and Nigeria," Chapter 4 in "IMF Financial Surveillance in Action: Country Case Studies from Europe and Sub-Saharan Africa," IEO Background Paper No. BP/18-02/09 (Washington: International Monetary Fund).

Partnoy, Frank, 2009, "Rethinking Regulation of Credit Rating Agencies: An Institutional Investor Perspective," University of San Diego Legal Studies Research Paper, No 09-014, April.

Persaud, Avinash, 2000, "Sending the herd off the cliff edge: the disturbing interaction between herding and market-sensitive risk management practices," Jacques de Larosiere Prize Essay (Washington: Institute of International Finance).

Rajan, Raghuram G., 2005, "Has Financial Development Made the World Riskier?" NBER Working Paper 11728 (Cambridge, MA: National Bureau of Economic Research).

Rivlin, Alice, and John Soroushian, 2017, "Credit Rating Agency Reform is Incomplete," The Brookings Institution, https://www.brookings.edu/research/credit-rating-agency-reformis-incomplete/, March 6.

Sarin, Natasha, and Lawrence Summers, 2016, "Understanding Bank Risk through Market Measures," Brookings Papers on Economic Activity, Fall.

Stedman, Louellen, 2018, "Strengthening IMF Financial Surveillance: Organizational and Human Resource Issues," IEO Background Paper No. BP/18-02/05 (Washington: International Monetary Fund).

Task Force on Climate-Related Financial Disclosures (TFCD), 2017, "Final Report: Recommendations of the Task Force on Climate-related Financial Disclosures, https://www.fsb-tcfd.org/publications/, June.

Veron, Nicolas, 2016, "The IMF's Role in the Euro Area Crisis: Financial Sector Aspects," IEO Background Paper BP/16-02/10 (Washington: International Monetary Fund). 
Venditti, Fabrizio, Francesco Columba, and Alberto Maria Sorrentino, 2018, "A Risk Dashboard for the Italian Economy," Banca d'Italia, Occasional Papers No. 425.

Vickers, John, 2017, "Banking reform nine years on," VoxEU. Available at https://voxeu.org/article/banking-reform-nine-years, September 18.

World Bank, 2007, "Bank Regulation and Supervision Survey." Available at https://www.worldbank.org/en/research/brief/BRSS. 